\title{
Geochemistry of Sandstone Type Uranium Deposit in Tarat Formation from Tim-Mersoi Basin in Northern Niger (West Africa): Implication on Provenance, Paleo-Redox and Tectonic Setting
}

\author{
Abdou Dodo Bohari1 ${ }^{*}$, Moussa Harouna1, Ali Mosaad ${ }^{2}$ \\ ${ }^{1}$ Department of Geology, Abdou Moumouni University, Niamey, Niger \\ ${ }^{2}$ Department of Mining and Metallurgical Engineering, Assuit University, Assuit, Egypt \\ Email: ^abdoubohari@yahoo.fr,mharounam@gmail.com,mossad_ali2000@aun.edu.eg
}

How to cite this paper: Bohari, A.D., Harouna, M. and Mosaad, A. (2018) Geochemistry of Sandstone Type Uranium Deposit in Tarat Formation from Tim-Mersoi Basin in Northern Niger (West Africa): Implication on Provenance, Paleo-Redox and Tectonic Setting. Journal of Geoscience and Environment Protection, 6, 185-225. https://doi.org/10.4236/gep.2018.68014

Received: May 11, 2018

Accepted: August 27, 2018

Published: August 30, 2018

Copyright $\odot 2018$ by authors and Scientific Research Publishing Inc. This work is licensed under the Creative Commons Attribution International License (CC BY 4.0).

http://creativecommons.org/licenses/by/4.0/

\begin{abstract}
The study aimed at investigating the geochemistry of a sandstone-type uranium deposit in Tarat formation for provenance, paleo-redox, tectonic setting in order to propose a geological model of uranium. X-Ray Fluorescence (XRF) and Induced Coupled Plasma Mass Spectrometry (ICP-MS) analyses were used to determine the sandstone composition. Major, trace and rare earth element compositions of the sandstones have been investigated to determine their provenance, tectonic setting and the influence of weathering conditions. Field studies of Tarat formation revealed that a major accident $\mathrm{N} 30^{\circ}$ that can be interpreted as an extension of the Austriche accident ensures the controls of Tarat sedimentation and mineralization deposits and the presence oxidized zone and reduced zone indicate the direction of circulation of the mineralized fluids from West to East. The uranium mineralization is disseminated as pitchblende that gives a yellow color to the sandstone while, molybdenum mineralization gives a blue color to the sandstone. Results of the Geochemical analysis indicate that the sandstone-type uranium deposit of Taratis classified into Protoquarzite (i.e. lithearenite and sublitharenite), arkose, subarkose, wacke and quartz arenite and varied in their maturity. Their Rare Earth Elements (REE) pattern displays high light REE over heavy REE, flat HREE and a significant negative $\mathrm{Eu}$ and $\mathrm{Ce}$ anomalies and in general correlated well with the NASC and PAAS average composition. The source area may have contained quartzose sedimentary rocks. The geochemical data support deposition in reducing environment of arid to humid climatic condi-
\end{abstract}


tions rich in organic matter affected by passive margin (PM) tectonic setting and the sediments are derived from felsic and mafic source rocks. Trace and REE data as well as the high values of the weathering indices: Chemical Index of Alteration (CIA), Plagioclase Index of Alteration (PIA) and Chemical Index of Weathering (CIW) suggest intermediate to extreme weathering conditions in the source area or during transportation. The studied sandstones are inferred as highly mature sediments evidenced from their high $\mathrm{SiO}_{2} / \mathrm{Al}_{2} \mathrm{O}_{3}>$ 1 and the presence of the ultra-stable clay minerals, smectite, kaolinite, chlorite and illite. Also the $\mathrm{Th} / \mathrm{U}<3$ ratio suggests high uranium enrichment of Tarat sandstones over crust average composition. From the factor analysis of the analyzed sandstone, there is no direct relationship between organic carbon and uranium, indicating the absence of organo-uraniferous composite and a major source derived from felsic to the mafic rock of Air Massif. The mineralized fluids of circulating from west to east are usually capped and underlain by impermeable mudstone or clay-rich units and uranium mineralization occurs in the association $\mathrm{U}-\mathrm{Mo}-\mathrm{Pb}$ or $\mathrm{U}-\mathrm{Zn}-\mathrm{Ni}-\mathrm{Pb}$ structurally controlled by the major fault in Azaoua lineament fault NS of Arlit in the West, the N70 ${ }^{\circ}$ Tin Adrar "faisceau" in the North, the N30" Mouron accident in the Southeast, N30 Autriche accident in the West and precipitated in areas of suitable reducing environment of arid to humid climatic conditions rich in organic matter affected by passive margin (PM) tectonic setting. The negative correlation of U-Th and U-Na in our samples indicates intense remobilization of uranium in Tarat formation.

\section{Keywords}

Uranium, Genesis, Geochemistry, Tarat Formation, Tim-Mersoi Basin

\section{Introduction}

The Tarat host formation of many deposits from the Tim-Mersoi basin in Arlit is located in the northwestern part of Niger Republic between $18^{\circ} 44^{\prime} 16^{\prime \prime}$ North latitude and $7^{\circ} 23^{\prime} 26^{\prime \prime}$ East longitude, about $200 \mathrm{~km}$ north of Agadez, west of the Aïr Massif (Figure 1). The Tarat formation is from the Carboniferous Upper Tagora Series. According to the following authors in [1] [2] [3] [4], the Tarat formation environment is rich in organic matter. Moreover, several scientists in [5]-[16] referred the provenance of Tarat sedimentary materials and uranium mineralization to dismantling of crystalline and crystallophyllic rocks of the air massif, to annular complexes of Zinder-Nigeria region, to volcanic alkaline emissions formed from emission of acid magmas and to the emplacement of plutons along major accidents such as that of Arlit.

In this research major, trace, REE geochemistry and factor analysis of geochemical data were used to infer the provenance, paleo-redox, tectonic setting and elements associated with uranium mineralization. Especially some immobile 


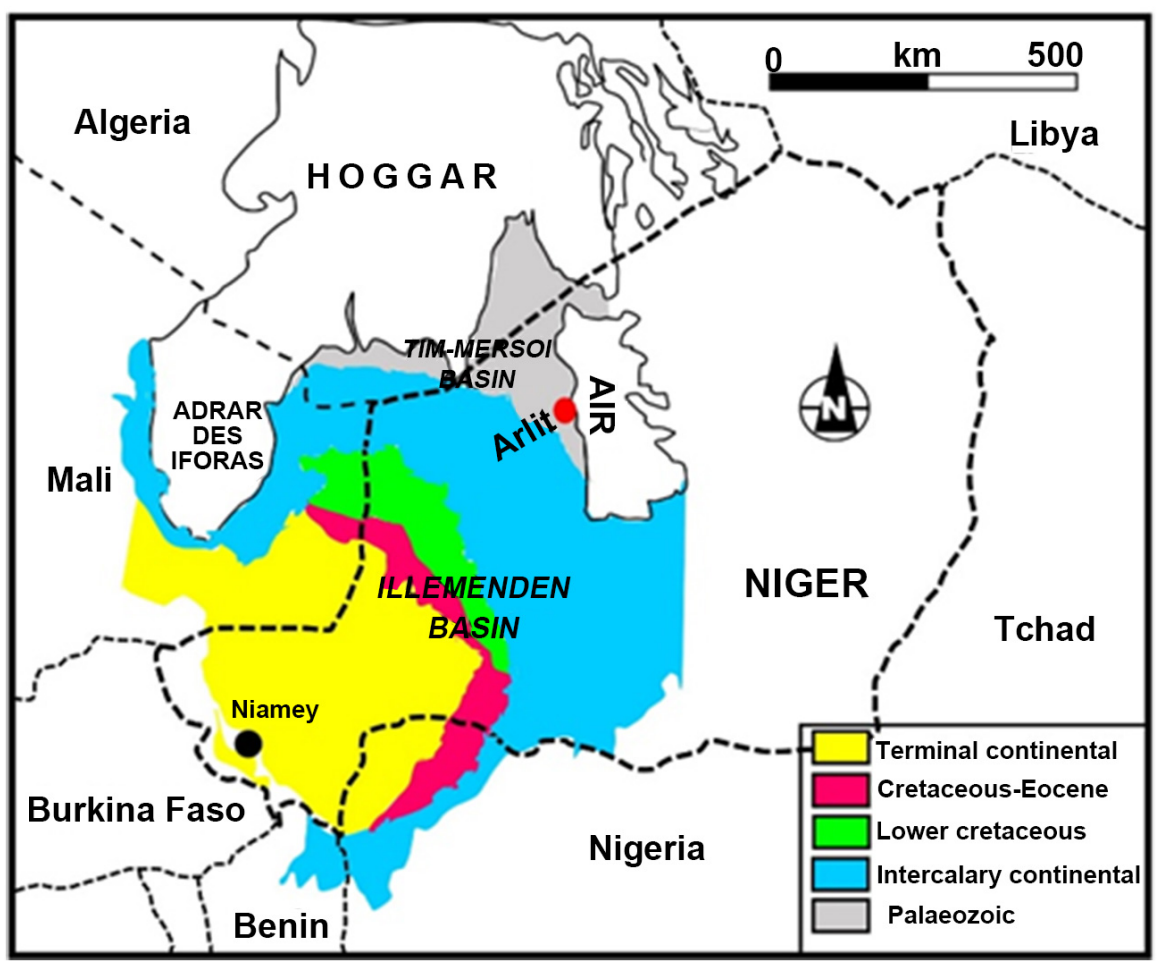

Figure 1. Geological map of the study area after [9], modified.

trace elements such as $\mathrm{Y}, \mathrm{Sc}, \mathrm{Th}, \mathrm{Zr}, \mathrm{Hf}, \mathrm{Cr}$, Co and REE were expected to be more useful in discriminating source rock compositions and tectonic setting due to their relatively low mobility during sedimentary processes and their short residence times in seawater [17]. These elements are probably transferred quantitatively into clastic sediments during weathering and transportation, reflecting the signature of the parent materials [17]-[26].

The deposits of Tarat formation are mining by SOMAIR for over a decade. In the current state of knowledge on these deposits, many questions remain about their depositional environment and genesis uranium mineralization. The objectives of our research study were therefore to document and update the geological knowledge of these deposits about provenance, paleo-redox and tectonic setting with a view to propose a simplified geological model of uranium for further exploration.

\section{Geological Setting}

The principal palaeogeographic characteristics of North and Central Africa during the onset of the Phanerozoic were the permanency of largely exposed lands over central Africa, surrounded by northerly and northwesterly dipping pediplanes, episodically flooded by epicontinental seas [27]. Phanerozoic African basins developed during the migration of the continent as part of Gondwana over the South Pole and northwards to its present position with the infill of basins by sedimentary material reflecting a change in paleoclimate [27]. The development 
and extent of these Phanerozoic basins are important due to their potential association with uranium [28].

Most of Niger comprises Phanerozoic sediment-filled basins coupled with Mesozoic and Cenozoic riftsystems as well as major fault zones (Figure 2). Pre-Cambrian or Proterozoic basement is located in the southwest and center of the country, which comprises crystalline and metamorphic rocks of the Air Massif [30].

The Iullemeden Basin, to the west of the Aïr Massif, is a vast structural depression of about $360,000 \mathrm{~km}^{2}$ covering virtually all of western Niger, with extensions in Algeria, Mali, Benin and Nigeria[7] [15] [31] (Figure 1). It is filled with up to $1500 \mathrm{~m}$ to $2000 \mathrm{~m}$ of sediments of alternating marine and continental origin. It covers an area of $800,000 \mathrm{~km}^{2}$ and borders the Adrardes Iforas, the Hoggar and the Aïr Massif in the north; the Gourma and Liptako Massifs and crystalline rocks of the Benin Republic to the west and the Nigerian basement

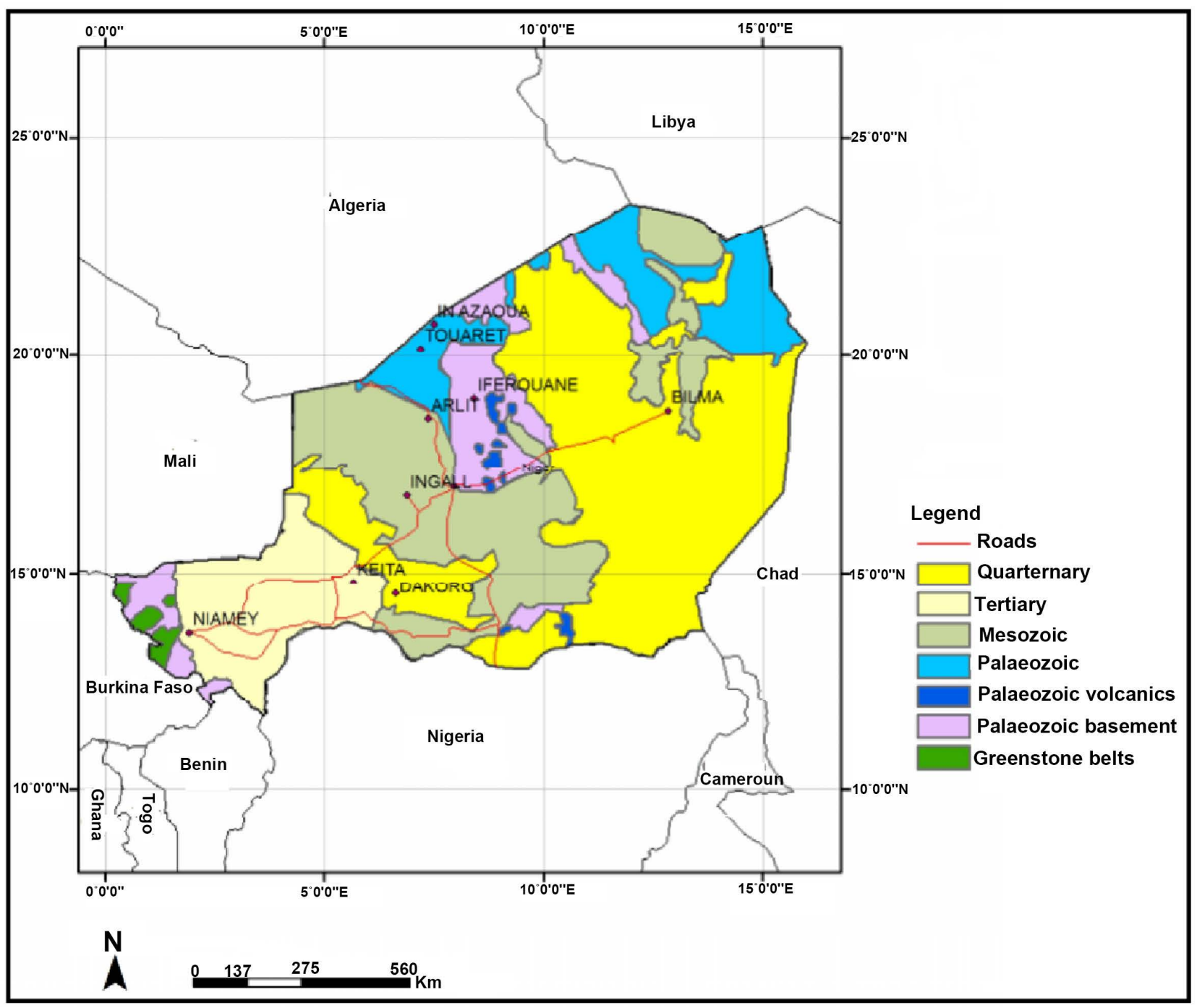

Figure 2. Distribution of Proterozoic basement and Phanerozoic basins in Niger [29] modified. 
rocks to the south and southeast. The basin is underlain by crystalline basement consisting of igneous and metamorphic rocks. The Iullemeden Basin is one of three important sub-Saharan inland basins consisting of a broadsyncline with gently dipping flanks. The syncline axis trend N-S between $3^{\circ}$ and $4^{\circ}$ longitudes. The overlying sedimentary sequences become progressively younger from the northeast to the southwest, indicating the directions of successive Cretaceous marine transgressions [30] [32]. Niger's main uranium resources are all contained in the sediments of the Tim Mersoibasin, which is mainly the continental part of the sedimentary layers of the Iullemmeden sedimentary basin. The large deposits currently mined by Cominak and Somair are located respectfully in the Lower Tagora and in the overlying Upper Tagora Series (Carboniferous) [33]. The continental sediments above the Carboniferous Period are termed the Continental intercalaire, which consist of the following units (Figure 3):

$>$ Tegama Group (Cretaceous Period) at the top;

Assaouas Series (Jurassic-Cretaceous Period);

Teloua Series (Triassic-Jurassic Periods);

Izegouandane Series at the base (Permian Period).

The geology of central Niger is dominated by the Air Massif which is a horst block of metamorphic rocks and calc-alkaline intrusives of Pre-Cambrian age, penetrated by over a dozen Palaeozoic (gabbro)-syenite-granite ring complexes. The Middle Continental series (Palaeozoic and Mesozoic formations) outcrop in the Tim Mersoibasin along the western margin of the Aïr Massif and comprises formations ranging from Cambrian to Cretaceous [33].

During the middle Paleozoic (Cambrian to Carboniferous Periods), sediment began to accumulate in a shallow lake. As the basin grew, the land to the east began to rise even as the basin continued to subside. The Carboniferous Terada as well as Lower and Upper Tagora Series were deposited during this time. The Terada Series consists of basal conglomerates andfluvio-glacial sandstones. The Lower and Upper Tagora Series consist of fluvio-deltaic sandstones. Each of these Series is overlainby marine shales or an alteration of shales and continental sandstones [30].

In the late Paleozoic, carbonate began to cement the sand and gypsum nodules grew in the mud. Whilst a rare mineral, analcime (feldspathoid requiring high $\mathrm{pH}$ and large concentrations of silica and sodium), formed thin beds in the Jurassic Period, carbonates again predominated during the end of the Cretaceous.

By the middle to end of the Mesozoic (Jurassic to Cretaceous Periods) highly alkaline volcaniceruptions began along a north-south line about $100 \mathrm{~km}$ east of the Tim Mersoi basin within the Aïr Massif. Volcanic rocks of this type carry high proportions $U$, thorium (Th), rare earth elements (REE), tin (Sn) and molybdenum (Mo) amongst others. The vitric ash from these volcanic eruptions dissolved in the Mesozoic waters, resulting in an increase in $\mathrm{pH}$ and carrying 


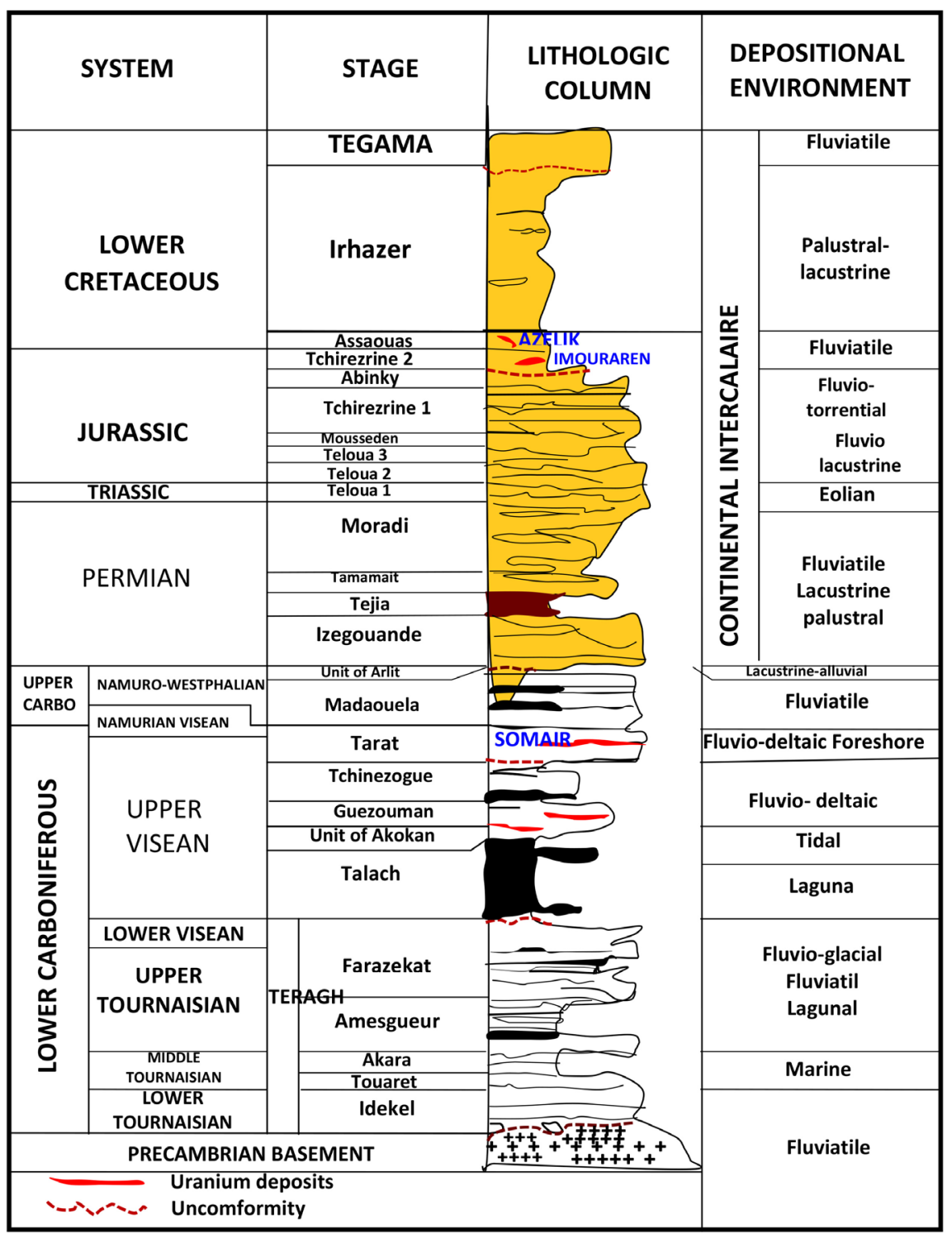

Figure 3. Litho-stratigraphic colonne of sedimentary series from devonian to lower cretaceous with the corresponding depositional environment in Tim-Mersoi basinafter [9] modified.

capacity of $\mathrm{U}$ in solution as uranylcarbonate complexes which were deposited under suitable organic-chemical conditions in the Jurassic-Cretaceous sediments of the Tim Mersoi basin [30]. The Paleozoic sequences thin towards the center of the basin, each overlapping the previous one from north to south and sedimentation is structurally controlled (Figure 4).

The tectonic structures of the Tim-Mersoi Basin are due to the tectonic adjustments along the Pan-African basement accidents. These adjustments compartmentalize the basin into the dorsal or goutier of different scales that control the processes of erosion and deposition [14] [15]. According to authors [34], the tectonic history of the Tim-Mersoi basin began in the Cambrian syncline in the Tin-Seririne. Subsequently, sedimentation moved southward, receiving 


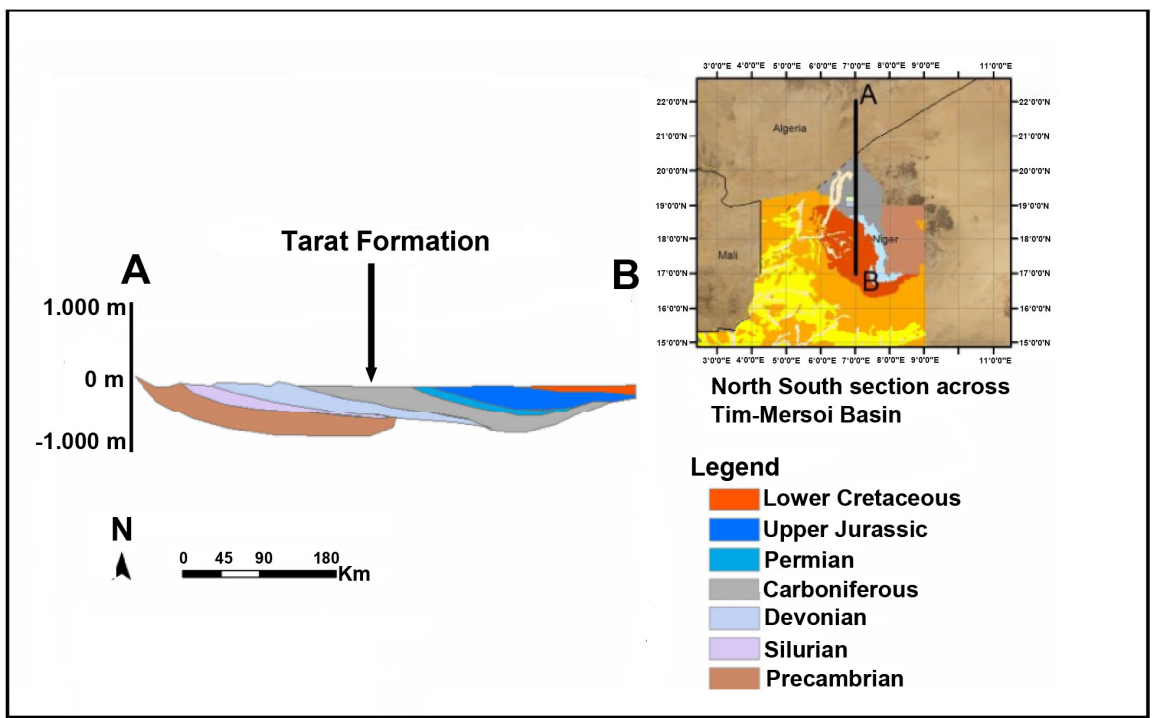

Figure 4. Geological section across the Tim Mersoibas in showing the position of the section on inset.

marginal-continental formations and coastal level which come systematically on the west edge of the Air Massif. Tim-Mersoi Basin is structured into a synclinal trough, with regional scale, affected by brittle (faults), mixed (flexures-faults) or by plicatives accident low amplitudes associated with progressive unconformities.Three major structures control the deposit system of Tarat formation such as the Lineament of ArlitIn AzaouaNS accident in the West, the N70 Tin Adrar "faisceau" in the North and the N30 Mouron accident in the Southeast (Figure 5 and Figure 6).

\section{Materials and Methods}

The approach methodologic adopted for this work consists of field work and laboratory analysis. The field work involved details geological study and sampling of Tarat formation in Takriza, Taza North, Tamou open pit mines and Tamari Prospect. Geochemical investigations based on the data of major, trace and rare earth elements were carried out. A total of 48 samples were chemically analyzed for their major and trace elements by X-Ray Fluorescence (XRF) in the Institute Instrumentation Center of Indian Institute of Technology, IIT Roorkee, India and Activation Laboratory (ActLab), Ontario, Canada while the REE was analyzed by Induced Coupled Plasma-Mass Spectrometry (ICP-MS) carried out in the analytical laboratory of Nanjing University, China. Geochemical data processing (factor and correlation analysis) was carried out by using statistical software SPSS-20. We have calculated the factors from the correlation matrix. The factor analysis includes the varimax rotation, which is a rotation of the factors around the orthogonal axes. Varimax rotation enhances differences in factor loadings. Factor loadings are the correlations between each variable and the factors. The sum of the squares of the factor 


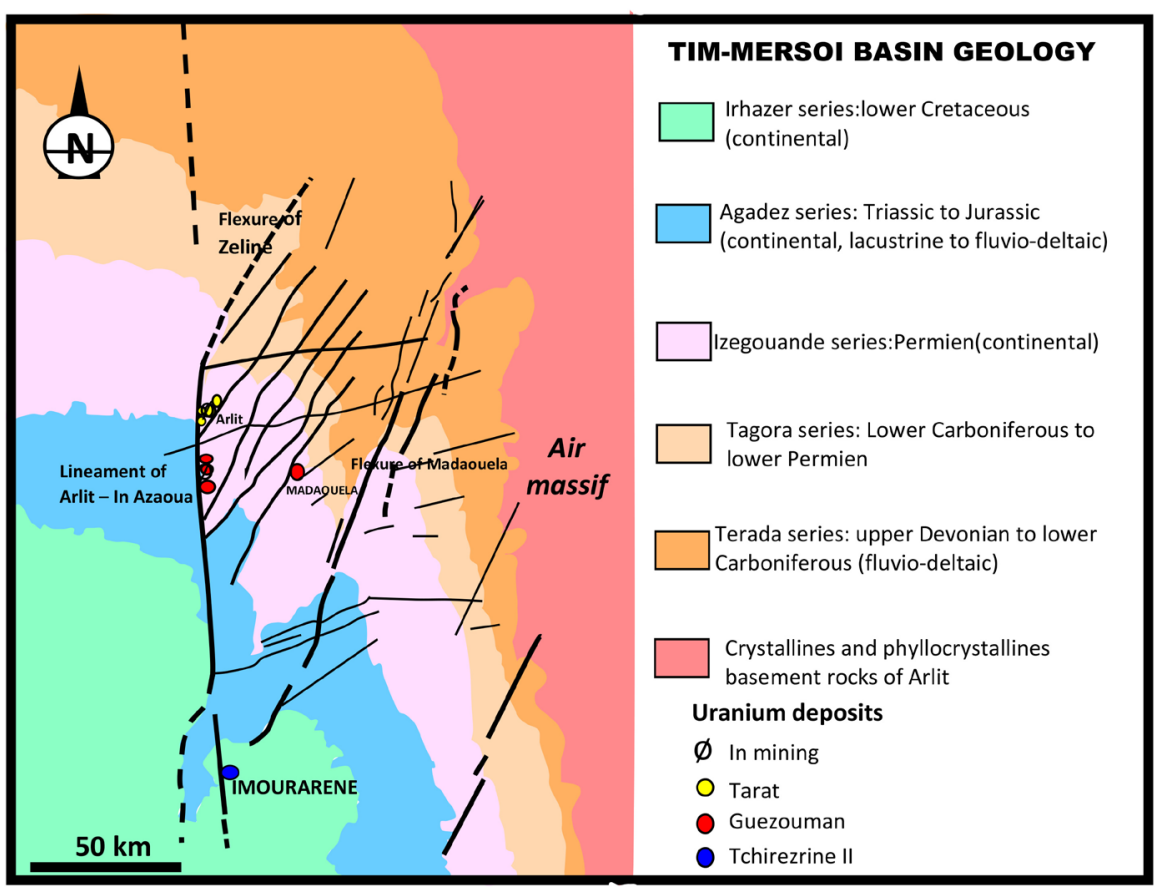

Figure 5. Geological and structural map of the edge of the Tim-Mersoï basin showing the study area and economic or sub-economic deposits of the Arlit region [9] modified.

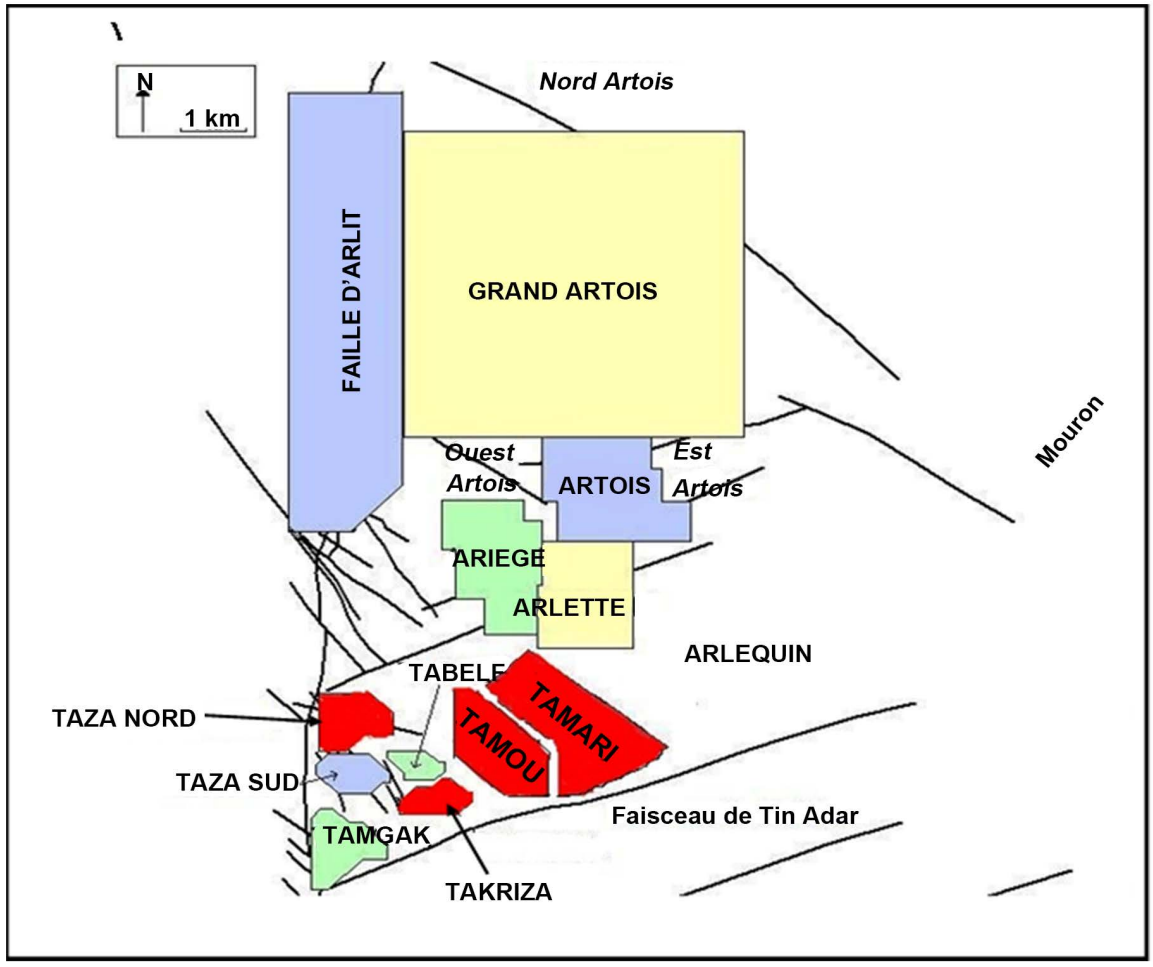

Figure 6. Position of Taza Nord, Takriza, Tamou and Tamari in red color.

loadings for each variable is equal to the communality, the proportion of each variable explained by the analysis. For more complete descriptions of factor analy- 
sis and its geological application see the following authors in [35] [36] [37] [38].

\section{Geology of Tarat Formation}

Geological studies of Tarat formation realized during this research include details field observations and sampling in three open pit mines areas such as Taza Nord, Takriza and Tamou while drilling core samples were collected in Tamari prospect area (Figure 6).

\subsection{Takriza Open Pit Mine}

The Tarat formation in Takriza mine is characterized by $\mathrm{N} 30^{\circ}$ accident that can be interpreted as an extension of the Austriche accident that controlling Tarat sedimentation and deposits of the mineralization (Figure 7). At the bottom of the mine the uranium mineralization, expressed as disseminated pitchblende in the sandstone, that gives a yellow color to this sandstone, and the sandstone with blue color indicates the association of uranium mineralization with molybdenum (Figure 8).

\subsection{Taza North Open Pit Mine}

The Tarat Formation in Taza North mine indicates the presence of oxidized sandstone and reduced sandstone indicating the direction of circulation of the mineralized fluids from west to east. In the oxidized zone, the sandstones are pinkish-gray indicating an intense oxidation state. Pyrite is not expressed macroscopically in this zone of intense oxidation. Upwards, this zone results in the reduction of oxidation intensity corresponding to the beginning of cementations of the host by pyrite or pitchblende. The radiometric measurement in this area is between 300 and 1000 counts/sec (SPP). In the reduced zone the sandstones are dark and sub-homogeneous in color with darker spots downwards. The radiometric measurement in this area is between 5000 and 8000 counts/sec (SPP). These observations suggest that the oxidized sandstone is weakly mineralized compared to reduced sandstone (Figure 9).

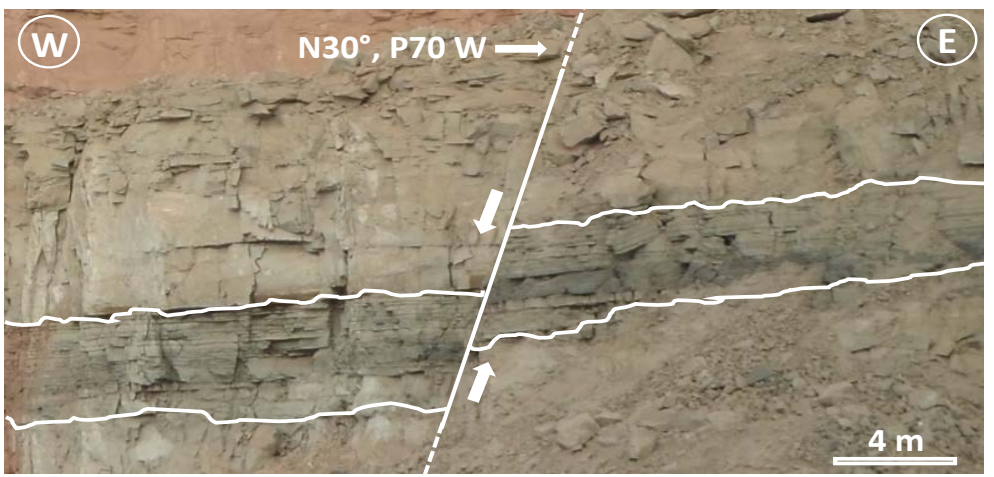

Figure 7. Tarat formation in Takriza is characterized by major accident $\mathrm{N} 30^{\circ}$. 


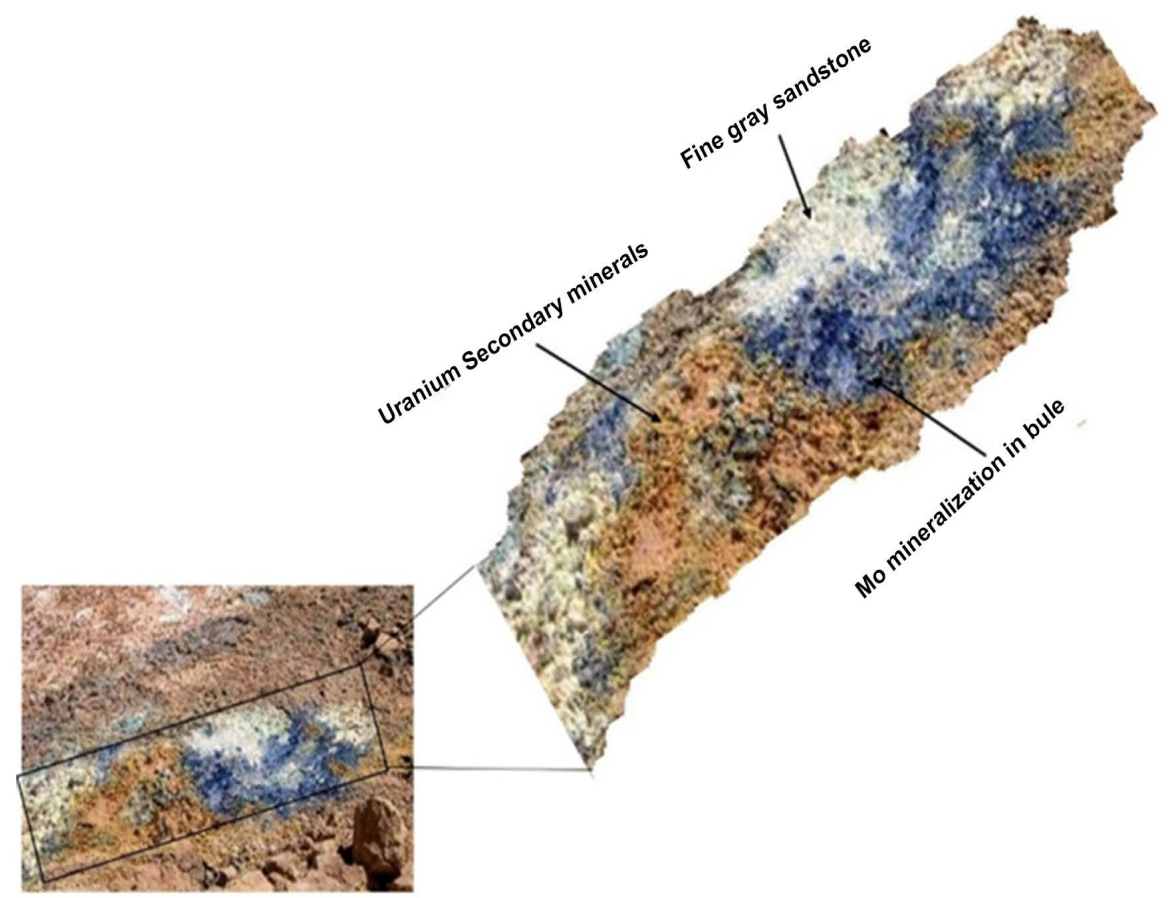

Figure 8. At the bottom of Takriza mine, Tarat formation shows the presence of Mo mineralization and $U$ secondary minerals.

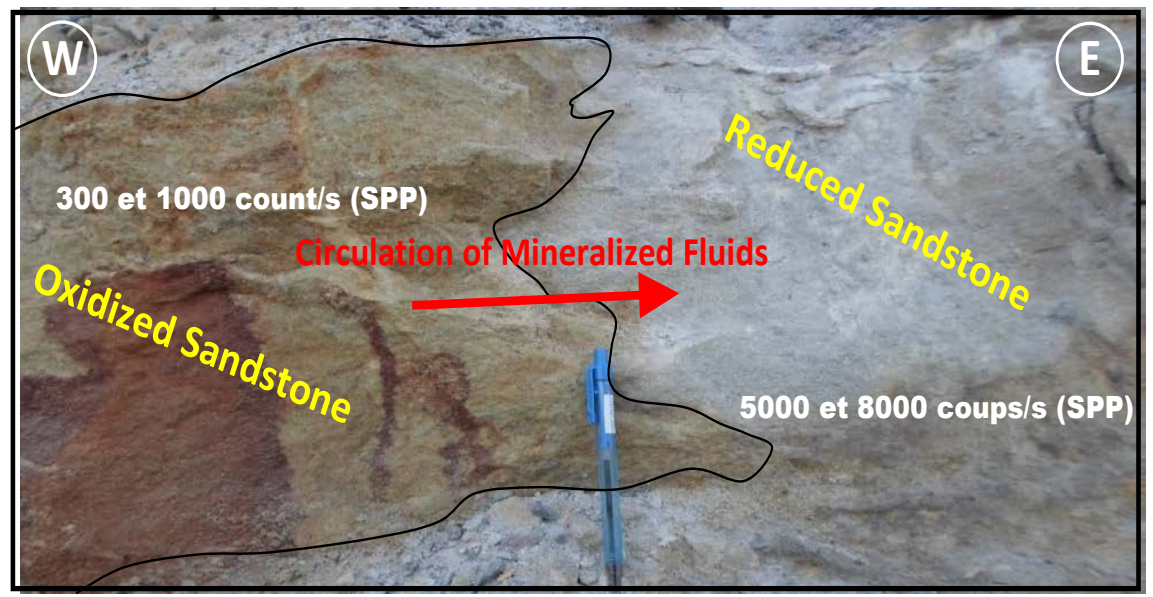

Figure 9. Tarat formation in Taza North shows the presence of oxidized and reduced sandstones.

\subsection{Tamou Open Pit Mine}

The Tarat formation in Tamou mine indicates alternation of gray coarse-grained sandstone and clay-silt of the massive structure with cross-stratification. These structures of plant debris rich in organic matter result from sediment deposition in fast flood flow regime. In such, environment the current resistance is low and the transport of the sediments important then the formation of the natural surfaces of sediments in wrinkles, sand waves or dunes is annihilated in favor of horizontal deposits under a relatively small slice of water (Figure 10). 


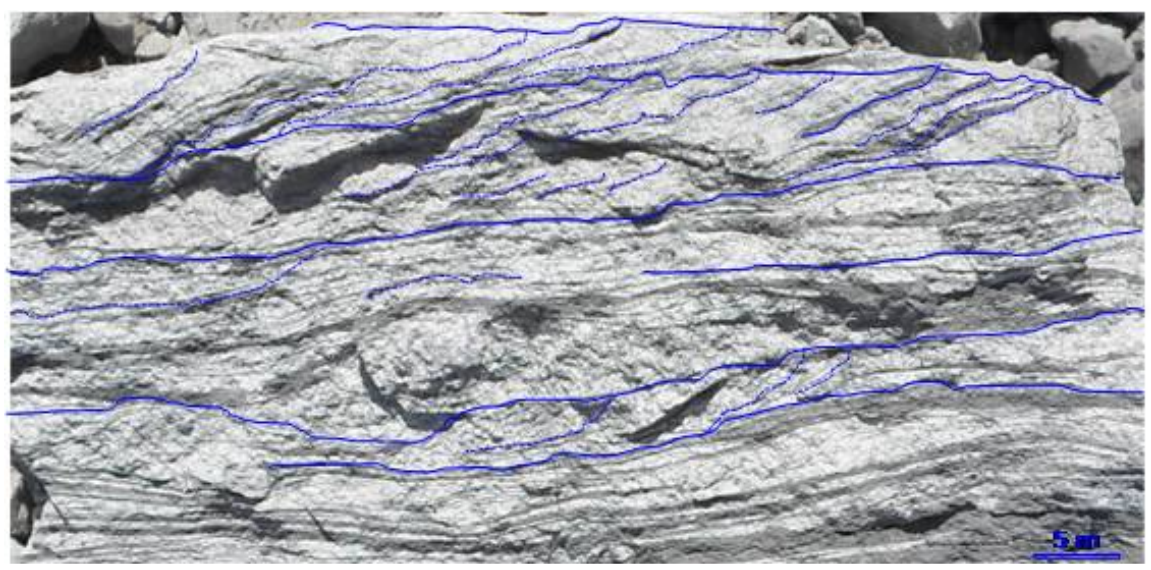

Figure 10. The Tarat formation studied in the Tamou open pit mine indicates alternation of gray coarse-grained sandstone and clay-silt of the massive structure with cross-stratification.

\subsection{Tamari Prospect}

The Tarat formation in TMRI 420 and TMRI 382 of Tamari prospect is divided into four sequences (Figure 11 and Figure 12) such as Unit 4 (U4) consisting of reduced gray fine consolidated sandstone alternating clay-silt (Figures 13(I)-(K)); Unit 3 (U3) composed of coarse to medium sandstone with increasing presence of micro-conglomerate towards the bottom (Figure 13(C), Figure 13(H) and Figure 13(I)); Unit 2 (U2) characterized by reduced fine gray sandstone with kaolinitic cement (Figure 13(A), Figure 13(C) and Figure 13(d)) and Unit 1 (U1) consists of coarse to micro-conglomerate gray sandstone (Figure 13(H)). The core samples are characterized by cross-stratification (Figure 13(G) and Figure $13(\mathrm{~L})$ ) and present a variation of the color yellow to red on the surface of the cores (Figures 13(B)-(D) and Figure 13(F)). These variations of colors can be interpreted as a significant index of uranium mineralization related to pitchblende dissemination.

\section{Geochemistry of Tarat Formation}

The geochemical results of major elements (Figure 14) reveal that Tarat sandstones have high $\mathrm{SiO}_{2}$ contents between 66.52 to 95.94 wt. percent with an average value of 81.47 wt. percent, which reflect quartz-rich nature of these studied sandstones following the criteria of [39] and the low ratio values of $\left(\mathrm{Al}_{2} \mathrm{O}_{3} / \mathrm{SiO}_{2}\right.$ $<1$ ) (Figure 15(A)), confirm the quartz enrichment in studied samples and high ratio values of $\left(\mathrm{SiO}_{2} / \mathrm{Al}_{2} \mathrm{O}_{3}>1\right)$ (Figure $15(\mathrm{~B})$ ) indicate high chemical maturity of the investigated samples.

$\mathrm{Al}_{2} \mathrm{O}_{3}$ content from the study area is relatively high ranging from 1.5 to 14.99 wt. percent with an average value of 8.39 wt (Figure 14) percent indicating the presence of feldspar and clay minerals in the Tarat sandstone samples [3].

The alkali and alkaline oxides, $\left(\mathrm{Fe}_{2} \mathrm{O}_{3}\right.$ and $\left.\mathrm{TiO}_{2}\right)$ are relatively low and ranges respectively from 1.39 to $7.87 \mathrm{wt}, 0.056$ to $1.079 \mathrm{wt}$. percent with a respective 
TMRI 420

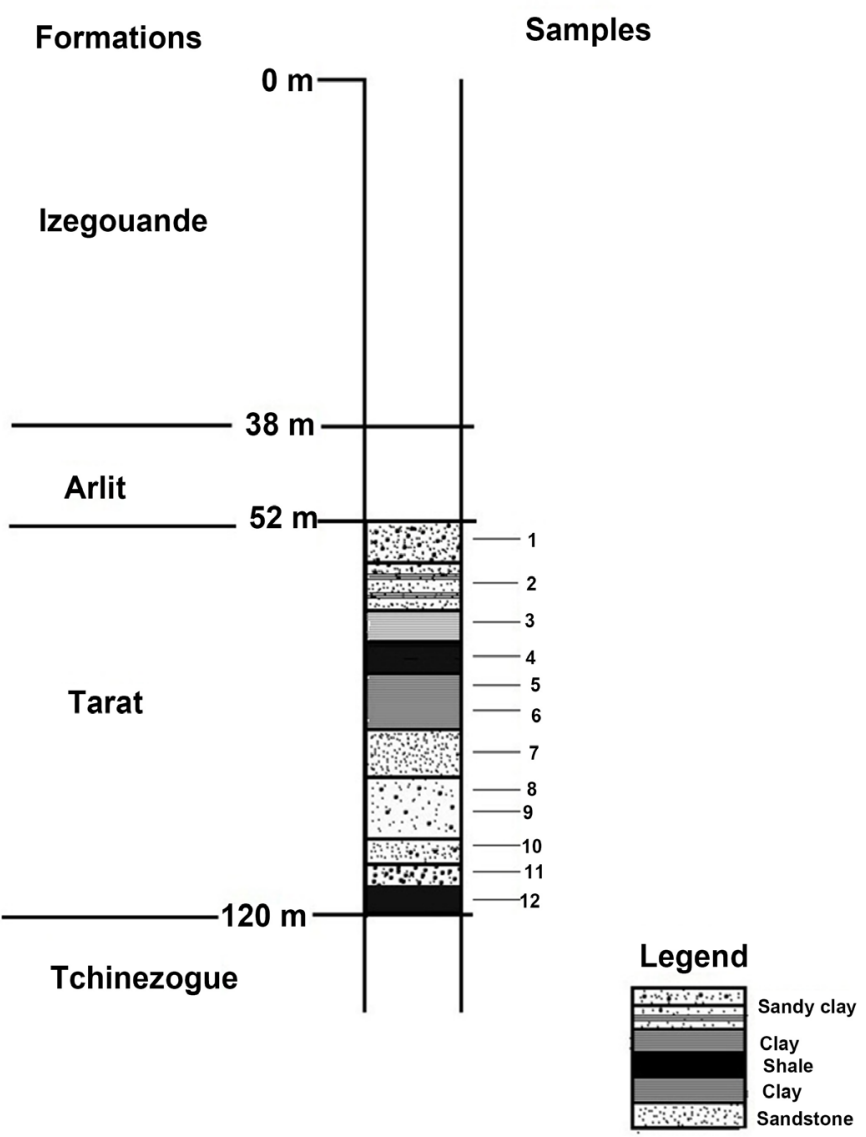

Figure 11. Lithological log of TMRI 420 in the Tamari Prospect showing four sequences of Tarat formation and samples locations.

average of $2.73 \mathrm{wt}, 0.5 \mathrm{wt}$. percent (Figure 14). Generally, low concentrations of $\mathrm{Fe}_{2} \mathrm{O}_{3}$ and $\mathrm{TiO}_{2}$ in all sandstones reflect low abundances of Ti-bearing minerals (biotite, ilmenite, titanite and titaniferous magnetite) in the analyzed samples [19] [40].

Depletion of $\mathrm{Na}_{2} \mathrm{O}(<1 \mathrm{wt} \%)$ and relative enrichment of $\mathrm{K}_{2} \mathrm{O}$ content in Tarat sandstones and the significantly higher ratio values of $\left(\mathrm{K}_{2} \mathrm{O} / \mathrm{Na}_{2} \mathrm{O}>1\right.$ ranging from 9 to 18) (Figure 15(C)) may probably suggest the presence of higher concentration of $\mathrm{K}$-feldspar in these sandstones.

$\mathrm{MgO}, \mathrm{MnO}$, and $\mathrm{P}_{2} \mathrm{O}_{5}$ are generally very low averaging $0.58,0.01$ and 0.03 wt. percent respectively (Figure 14). The increase of loss on ignition is related to the presence of kaolinite and mica. The low values of $\mathrm{P}_{2} \mathrm{O}_{3}$ (averaging 0.03 wt. percent) and $\mathrm{CaO}$ contents indicates low content apatite in studied samples.

The trace elements of Tarat sandstones generally varied in their concentrations (Figures 16-19). However, Th, V, Zn, Pb, Mo, Zr, U, Ba, Rb, Sr, Ni, Cr and $\mathrm{Cu}$ are relatively high; while TI, Sn, $\mathrm{Ag}, \mathrm{Ta}, \mathrm{W}, \mathrm{Cs} \mathrm{Sc}, \mathrm{Be}, \mathrm{Co}, \mathrm{Ga}, \mathrm{As}, \mathrm{Y}, \mathrm{Hf}$ and $\mathrm{Nb}$ have low content values. 


\section{TMRI 382}

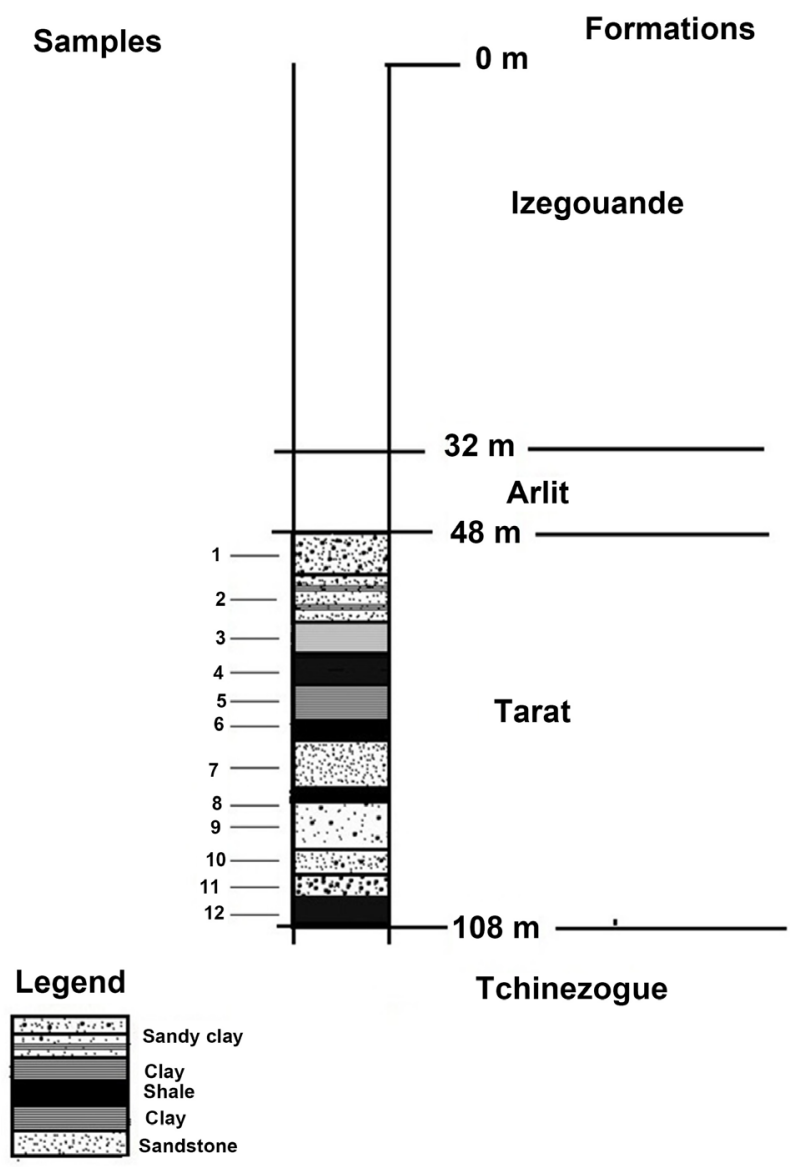

Figure 12. Lithological log of TMRI 382 in the Tamari Prospect showing four sequences of Tarat formation and samples locations.
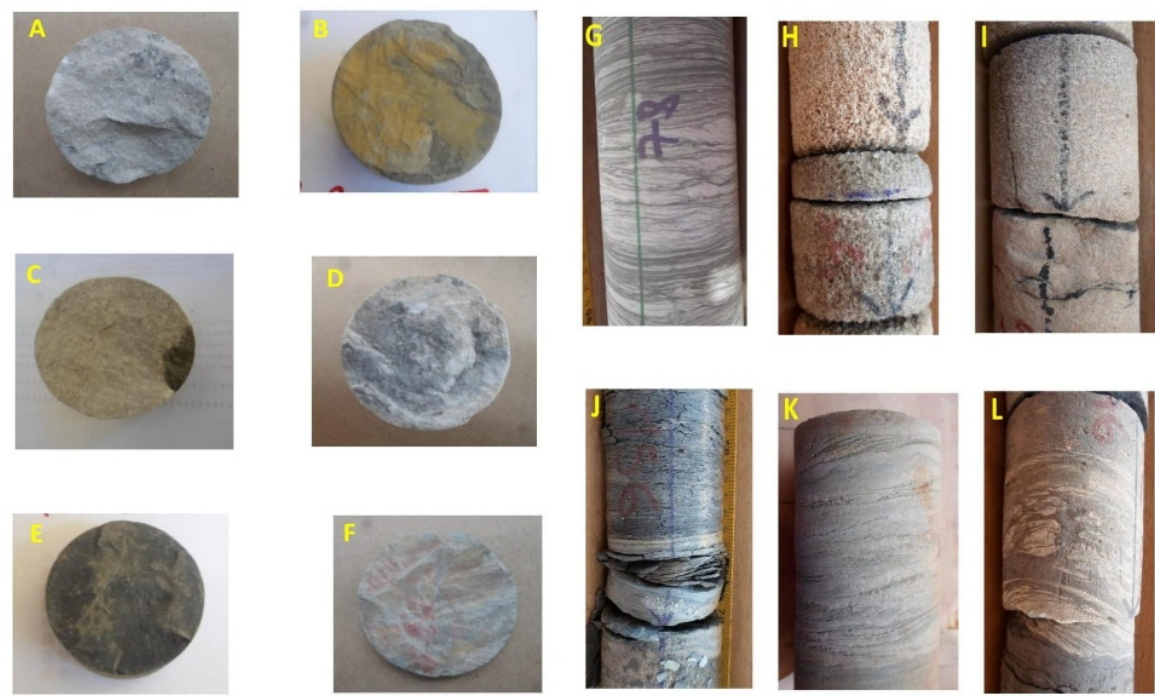

Figure 13. Drill cores samples of Tamari prospect area with yellow to red color and cross-stratification. 


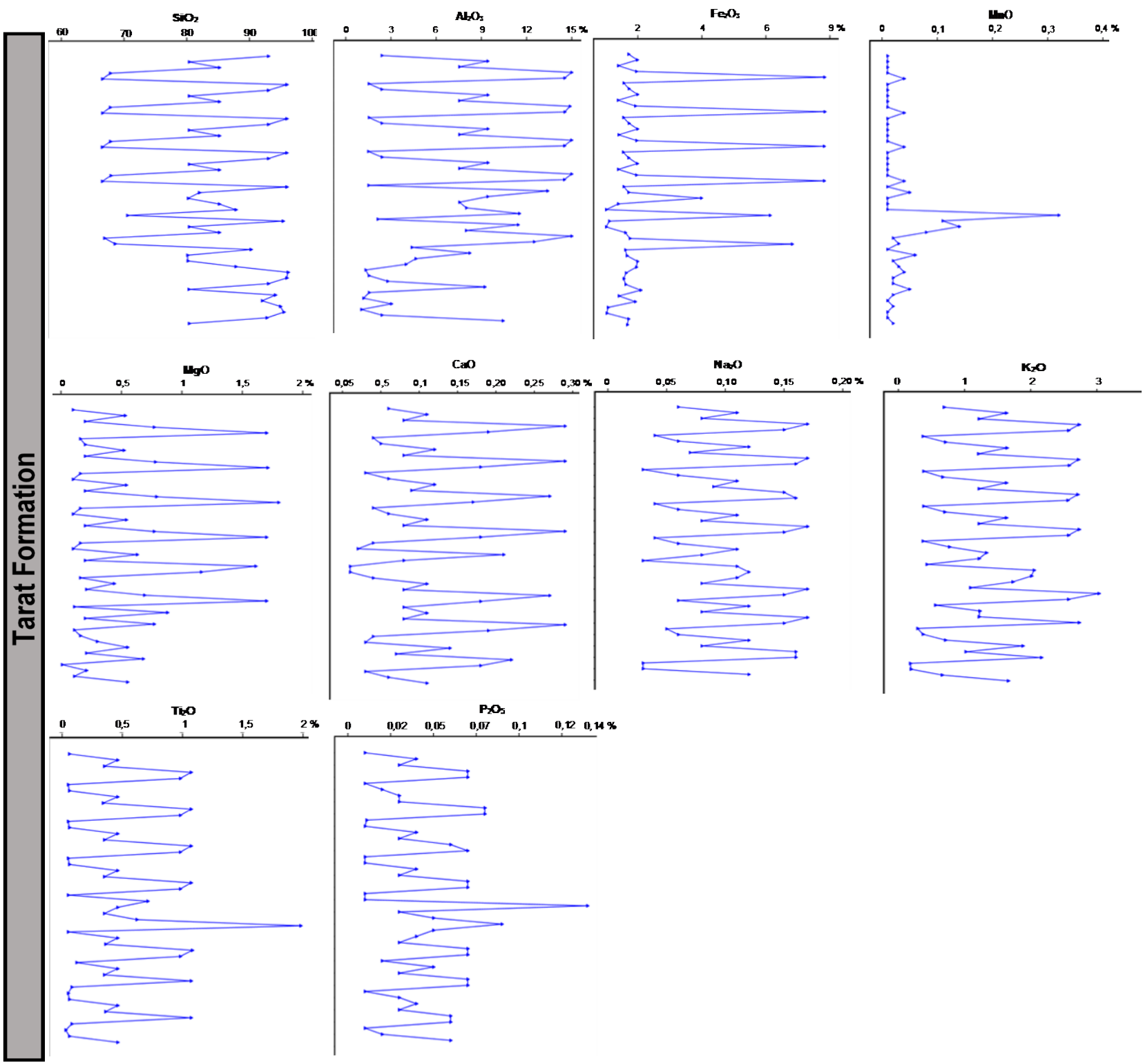

Figure 14. Geochemical profile of major elements in Tarat formation.

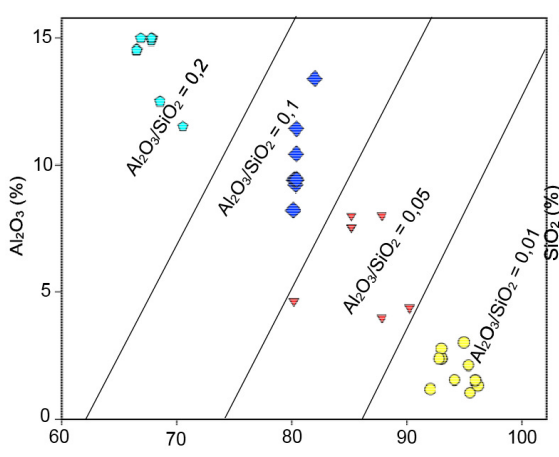

(A)

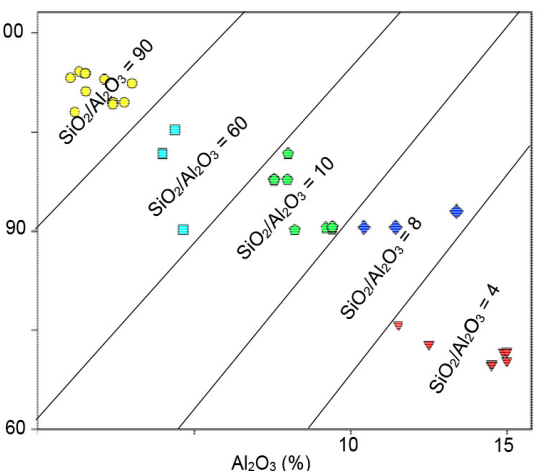

(B)

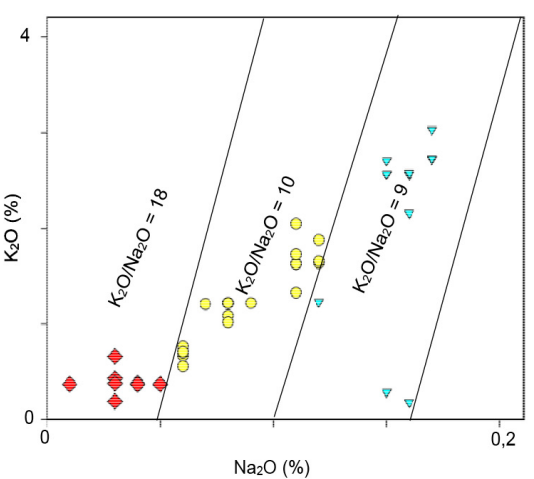

(C)

Figures 15. (A) Ratio of $\mathrm{Al}_{2} \mathrm{O}_{3} / \mathrm{SiO}_{2}$; (B) Ratio of $\mathrm{SiO}_{2} / \mathrm{Al}_{2} \mathrm{O}_{3}$ and (C) Ratio of $\mathrm{K}_{2} \mathrm{O} / \mathrm{Na}_{2} \mathrm{O}$. 


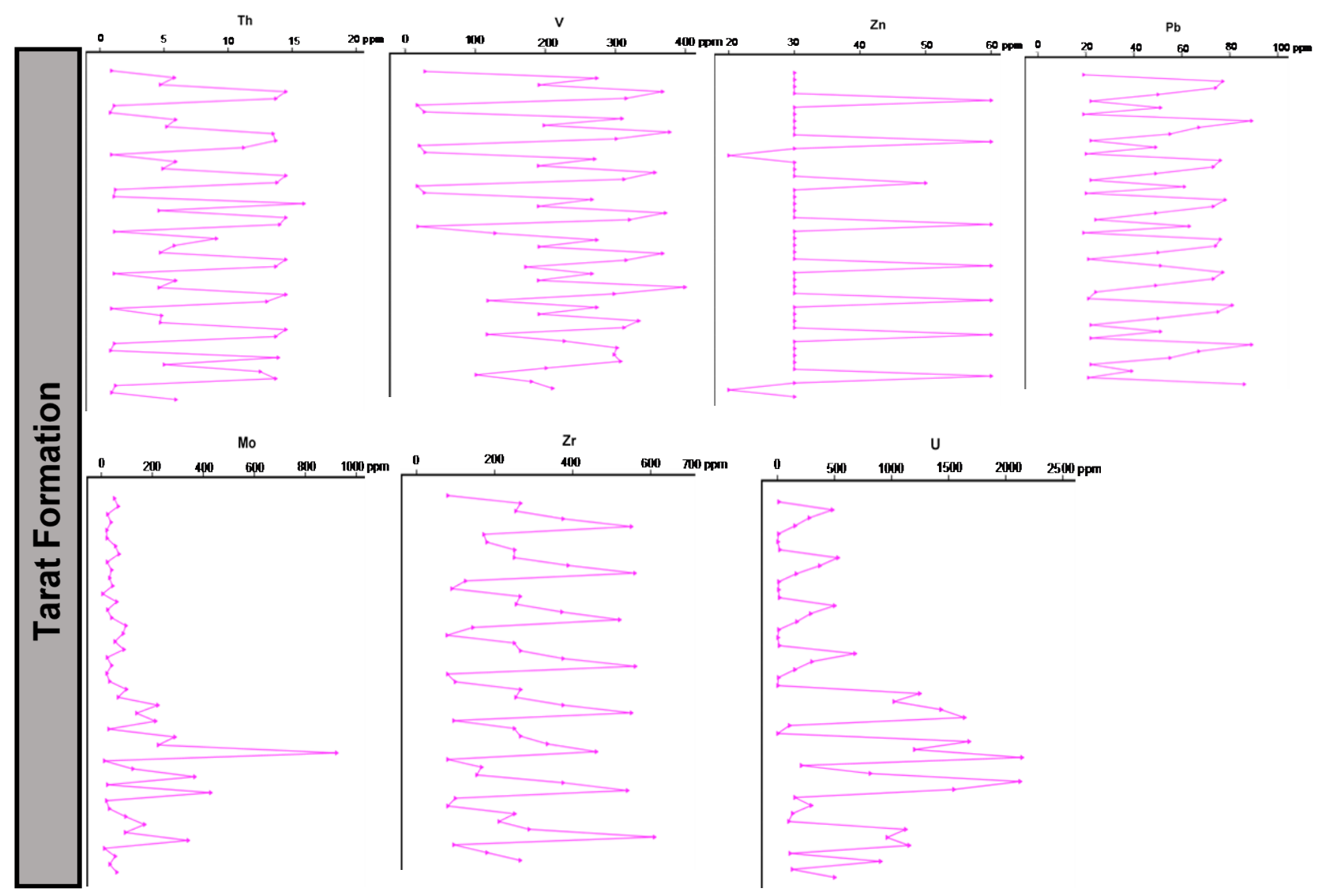

Figure 16. Geochemical profile of Th, V, Zn, Pb, Mo, Zr and U in Tarat Formation.

The rare earth elements are generally divided into two sub-groups: light rare earth elements (LREE) (from La to Eu) and heavy rare earth elements (HREE) (from Gd to Lu). The geochemical profiles (Figure 20 and Figure 21) of the Tarat formation REE indicate that LREE elements such as La, Ce and Nd have high values contents more than $50 \mathrm{ppm}$ while the concentrations of $\mathrm{Pr}, \mathrm{Sm}$ and $\mathrm{Eu}$ are less than 50 ppm (Figure 20). However, the HREE elements such as Gd, Dy, Er, $\mathrm{Yb}, \mathrm{Ho} \mathrm{Tb}$ and $\mathrm{Lu}$ have low quantities values generally less than $10 \mathrm{ppm}$ (Figure 21).

The REE of Tarat sandstones are shown as chondrite-normalized patterns compared to NASC (North American Shale Composite) and PAAS (Post-Archean Australian Shale) sedimentary standards in (Figures 22(A)-(E)). In general, chondrite-normalized REE patterns for the studied sandstone from Tarat formation are characterized by high LREE, flat HREE pattern, and pronounced negative Eu anomaly (Figures 22(A)-(E) and Figure 23(A)). LREE are fractionated and the HREE patterns are almost flat, indicating the presence of monazite that may be responsible for the concave-convexforme of Tarat patterns [6]. The ratio $(\mathrm{La} / \mathrm{Yb})_{\mathrm{N}}>0$ in all samples (Figure 23(B)) confirm the enrichment LREE over HREE. This chondrite-normalized pattern is typical of sediments and sedimentary rocks enrichment in LREE, flat heavy HREE and negative Eu anomaly [41]. 


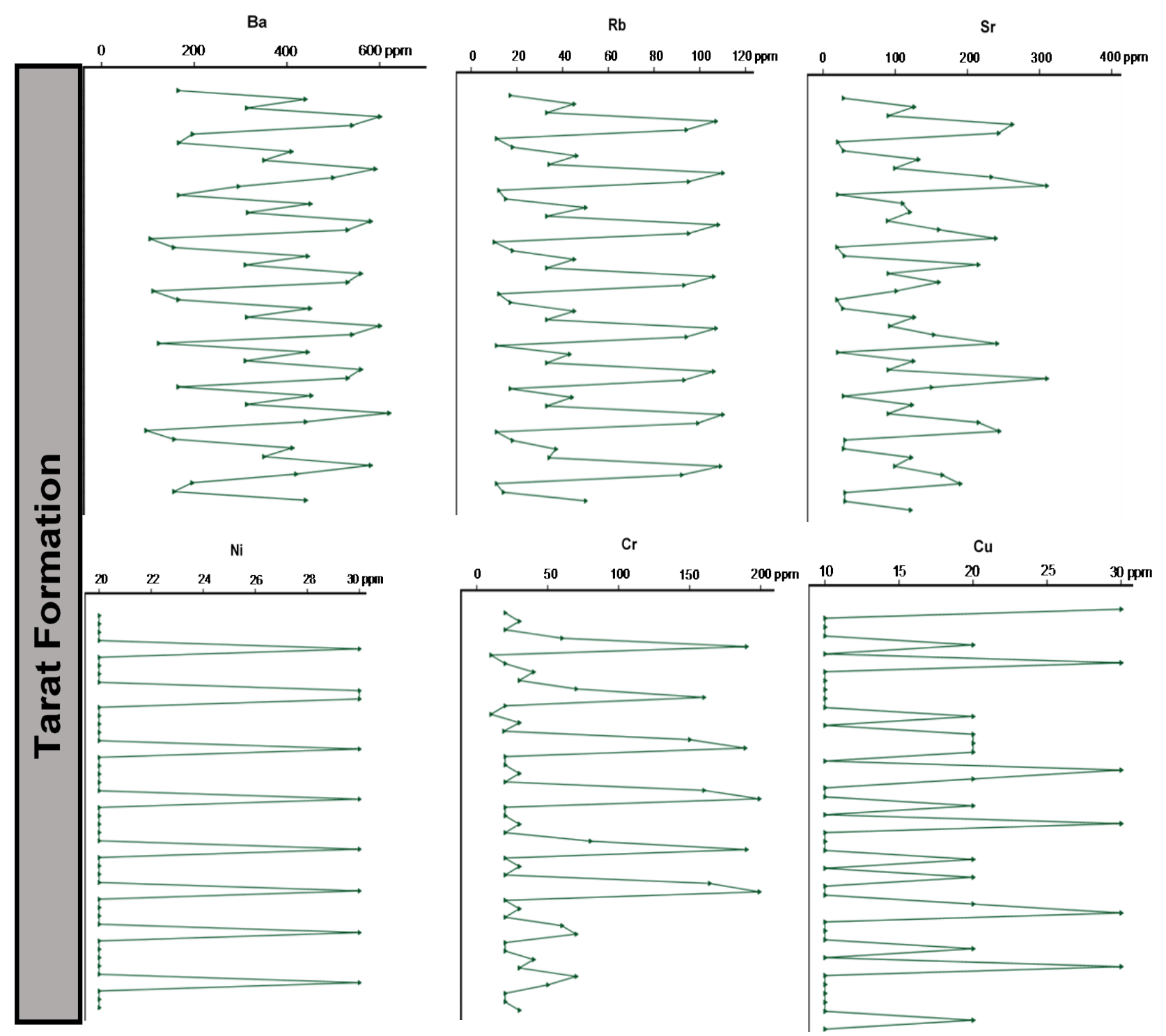

Figure 17. Geochemical profile of $\mathrm{Ba}, \mathrm{Rb}, \mathrm{Sr}, \mathrm{Ni}, \mathrm{Cr}$ and $\mathrm{Cu}$ in Tarat Formation.

The chondrite-normalized REE patterns for Tarat sandstones (Figures 22(A)-(E)) are similar to that displayed by NASC and PAAS. The Ce anomaly of Tarat formation is always negative, ranging from 0.2 to 0.99 (Figures 22(A)-(E) and Figure 23(C)) which is quite related either to the abundance of heavy minerals such as garnet, zircon monazite or pitchblende or hydrothermal fluid leaching [16].

\subsection{Classification of Tarat Samples}

Sandstones are classified variously based on their chemical composition [42] [43] [44]. Depended on the concentration of three major oxide groups: silica and alumina, alkali oxide, and iron oxide plus magnesia [45], by using bivariate diagram plot of [43], the Tarat Sandstones can be classified into Protroquartzite 


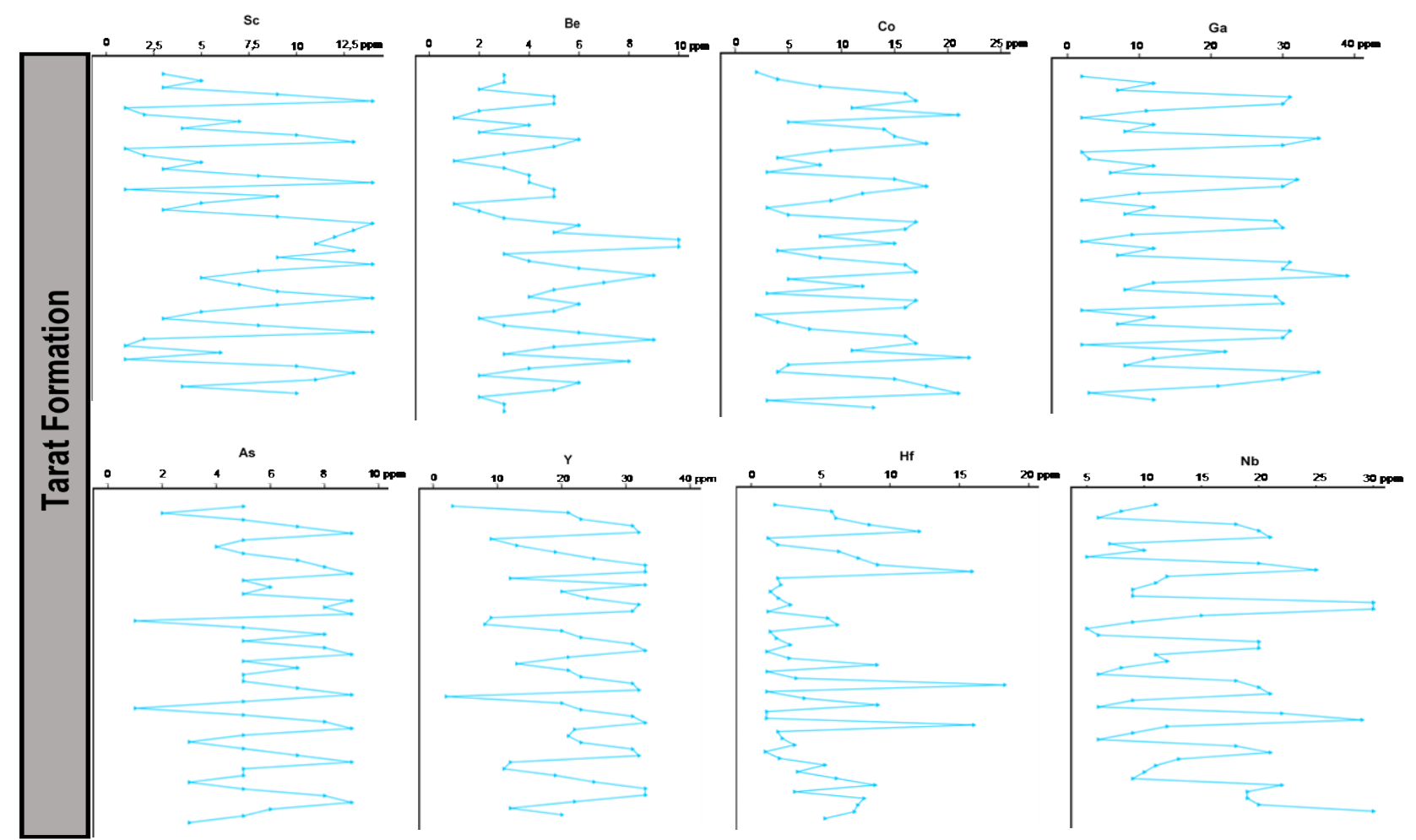

Figure 18. Geochemical profile of $\mathrm{Sc}, \mathrm{Ba}, \mathrm{Co}, \mathrm{Ga}, \mathrm{As}, \mathrm{Y}, \mathrm{Hf}$ and $\mathrm{Nb}$ in Tarat Formation.

(i.e. lithearenite and sublitharenite), arkose, subarkose, wacke and quartz arenite (Figure 24).

\subsection{Provenance}

The authors in [17] [18] [19] [21] [46] [47] [48] noted that the geochemical compositions of sedimentary rocks are related to those of their source and this principle has been used to characterize the source rocks from which the investigated sedimentary rocks were derived. In order to refer the provenance of Tarat sandstones, the discrimination functions diagram of [49] has been used to construct the provenance of these sandstones (Figure 25). This diagram reveals that the plotted sandstones were derived from granitic-gneissic source or pre-existing sedimentary source. The position of the studied samples deep into the discrimination functions diagram is similar to that observed for several recycled suites elsewhere [17] [50] [51]. This was interpreted as the effect of recycling, with progressive loss of feldspar and relative increase in quartz. The deeper plot position of Tarat samples may therefore reflect more advanced weathering and maturation in these fluvial sediments.

Discriminant Function $1=\left(-1.773 \times \mathrm{TiO}_{2} \%\right)+\left(0.607 \times \mathrm{Al}_{2} \mathrm{O}_{3} \%\right)+(0.76 \times$ $\left.\mathrm{Fe}_{2} \mathrm{O}_{3} \mathrm{~T} \%\right)+(-1.5 \times \mathrm{MgO} \%)+(0.616 \times \mathrm{CaO} \%)+\left(0.509 \times \mathrm{Na}_{2} \mathrm{O} \%\right)+(-1.22 \times$ $\left.\mathrm{K}_{2} \mathrm{O} \%\right)+(-9.09) ;$ Discriminant Function $2=\left(0.445 \times \mathrm{TiO}_{2} \%\right)+(0.07 \times$ $\left.\mathrm{Al}_{2} \mathrm{O}_{3} \%\right)+\left(-0.25 \times \mathrm{Fe}_{2} \mathrm{O}_{3} \mathrm{~T} \%\right)+(-1.142 \times \mathrm{MgO} \%)+\left(0.432 \times \mathrm{Na}_{2} \mathrm{O} \%\right)+(1.426$ $\left.\times \mathrm{K}_{2} \mathrm{O} \%\right)+(-6.861)$. 


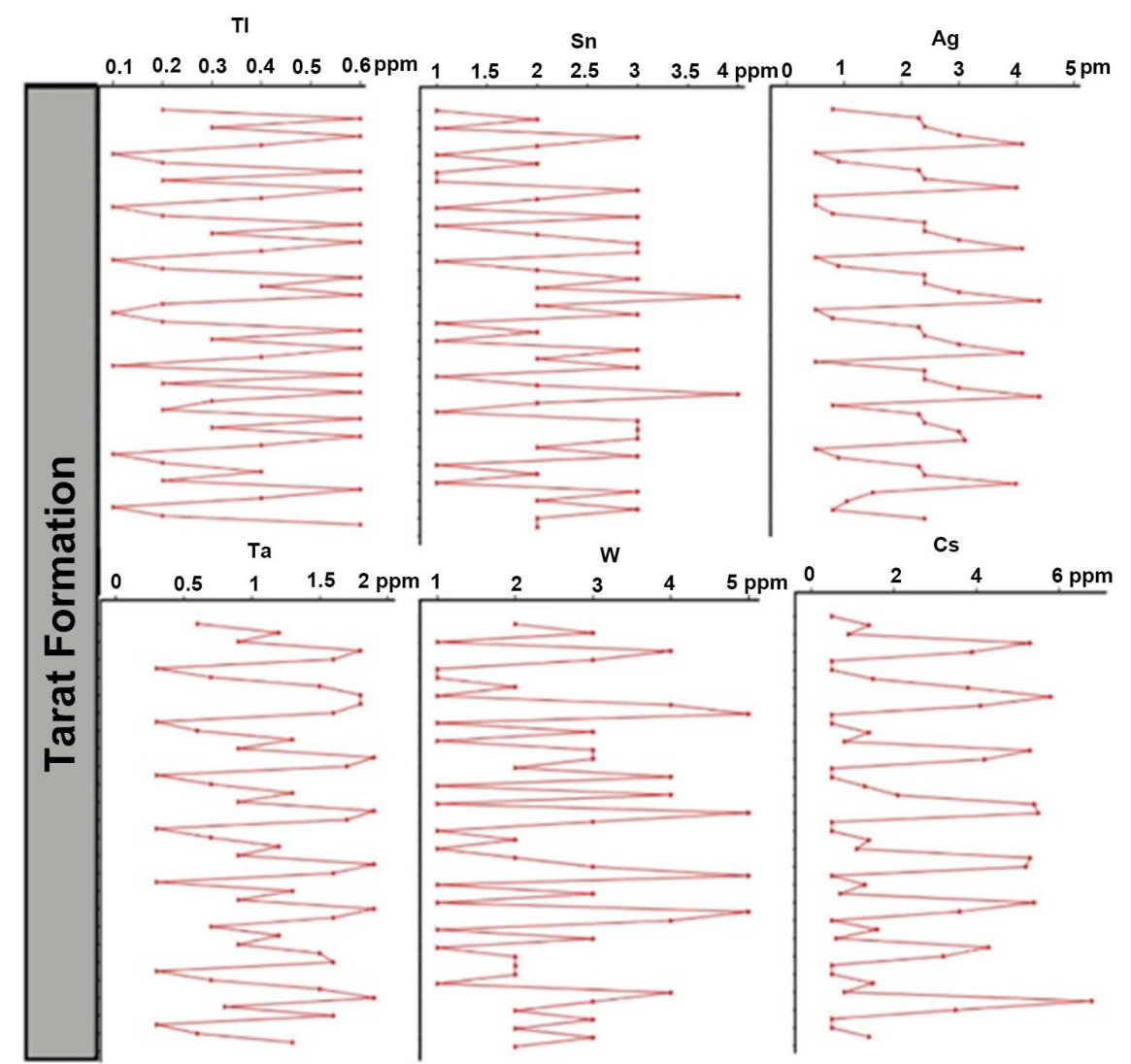

Figure 19. Geochemical profile of TI, Sn, Ag, Ta, W and Cs in Tarat Formation.

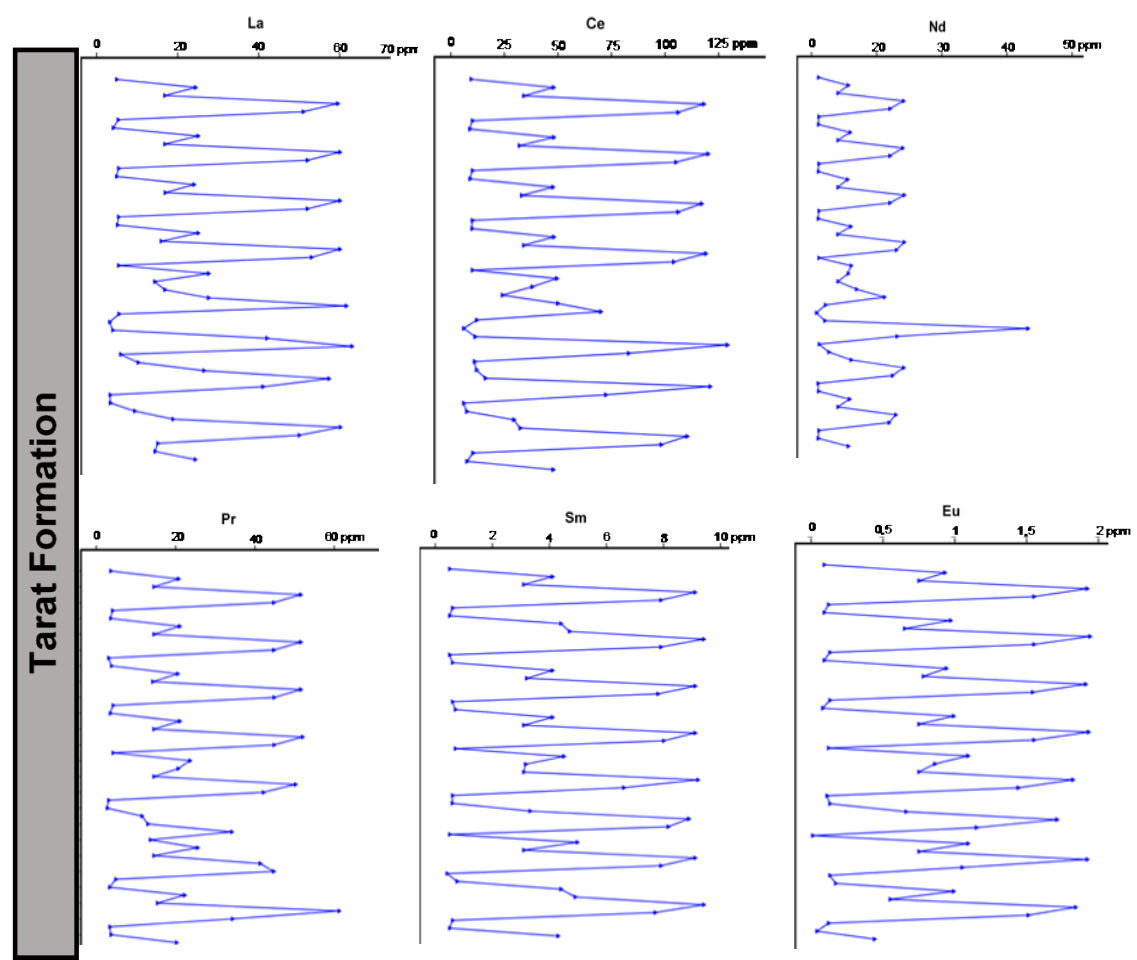

Figure 20. Geochemical profile of LREE ( $\mathrm{La}, \mathrm{Ce}, \mathrm{Nd}, \mathrm{Pr}, \mathrm{Sm}$ and $\mathrm{Eu}$ ) in Tarat Formation. 


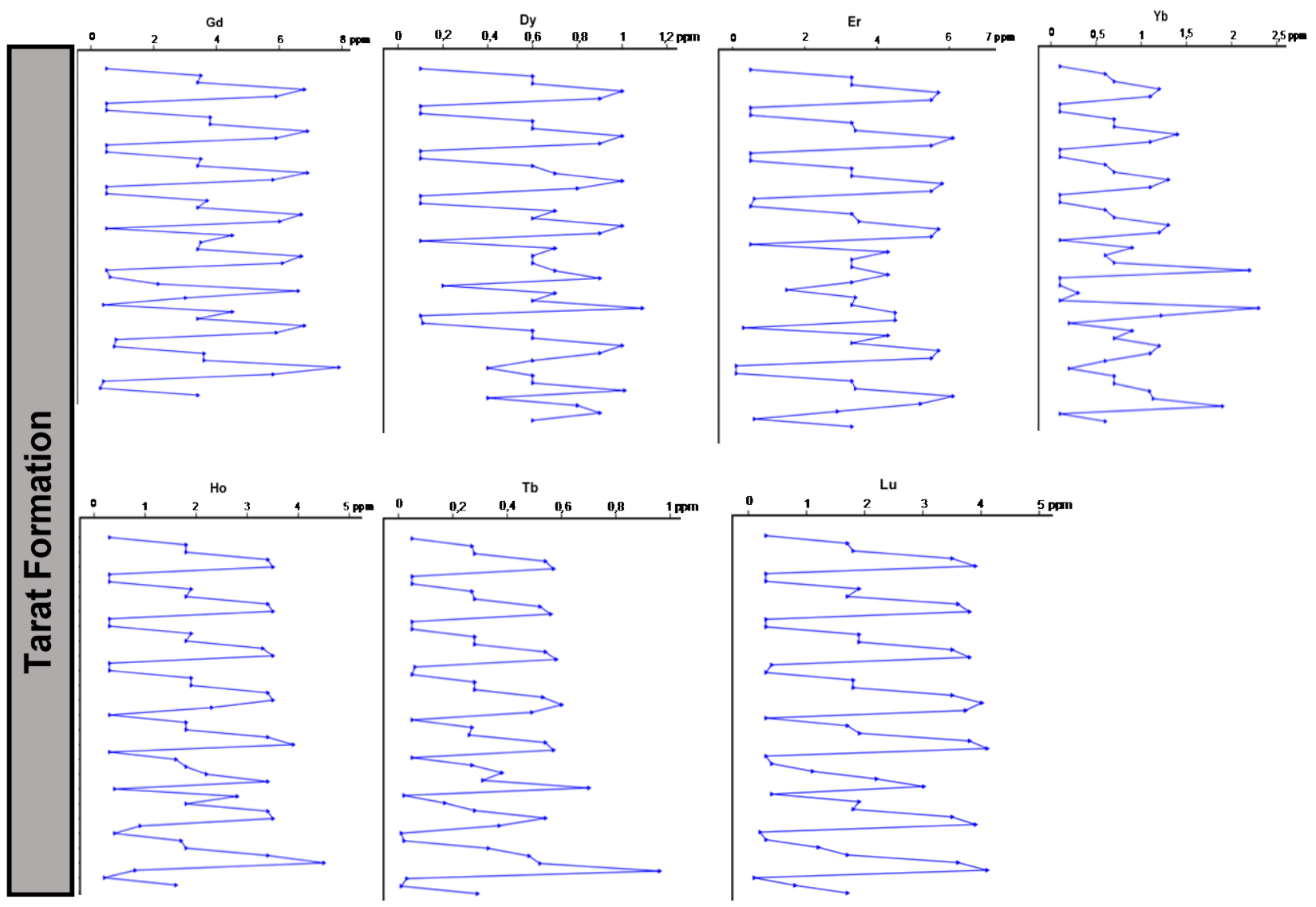

Figure 21. Geochemical profile of HREE (Gd, Dy, Er, Yb, Ho, Tb and Lu) in Tarat Formation.

Some trace elements such as $\mathrm{Zr}, \mathrm{Th}, \mathrm{Nb}, \mathrm{Ti}, \mathrm{Co}$, and $\mathrm{REE}$ are considered to have low mobility during sedimentary processes and can be used to access the source composition of sediments [26] [52] [53] [54] [55] [56]. During the sedimentary process the concentrations of these elements can vary thus, their ratios are considered to be more reliable [42] [47] [56] [57] [58] [59]. The studied sandstones are characterized by high Zrcontents (Figure 16), higher $\mathrm{Ba} / \mathrm{Co}$, $\mathrm{Zr} / \mathrm{Nb}, \mathrm{U} / \mathrm{Th}, \mathrm{Zr} / \mathrm{Th}$ ratios (Figures 26(A)-(D)) and relatively low Ti/Zr, Th/La, $\mathrm{Th} / \mathrm{Co}$ and $\mathrm{Th} / \mathrm{U}$ ratios (Figures $16(\mathrm{E})-(\mathrm{I})$ ). These features reflect the increased abundance of heavy mineral mainly zircon of these sediments, through sedimentary processes.

The ratios of $\mathrm{Th} / \mathrm{Co}$ vs. $\mathrm{Zr} / \mathrm{Co}$ plot has been used to differentiate between felsic and mafic nature of source rocks [22] [60]. In this plot (Figure 27), the studied samples show double source provenance mafic and felsic of Tarat sandstones.

From the above-mentioned observations the provenance of the studied sandstones can be explained by a sedimentary system dominated by detritus derived from recycled highly weathered granite-gneiss terrain and/or from pre-existing sedimentary terrain materials. The trace element ratios are consistent with most sandstone being derived from a double source mafic and felsic. 


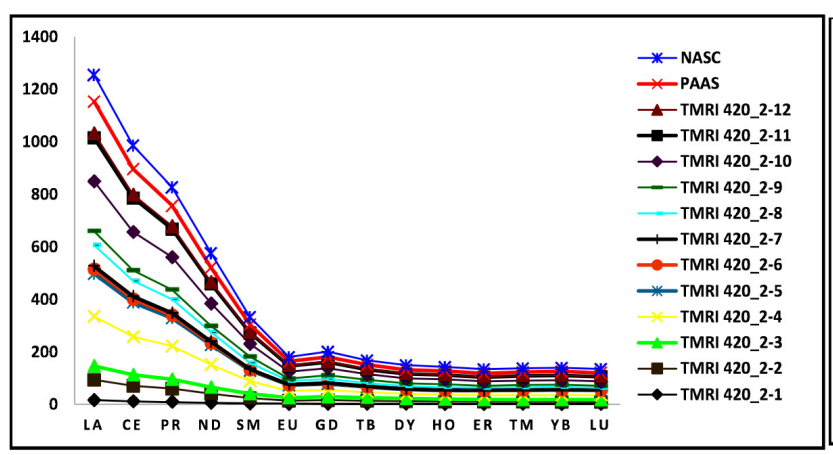

(A)

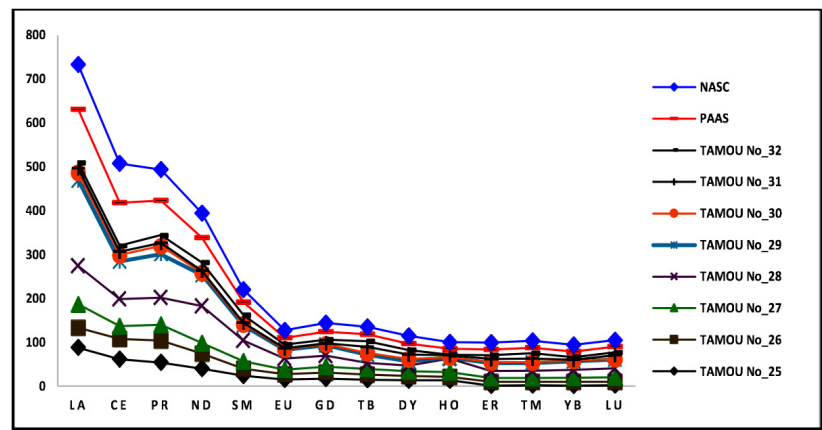

(C)

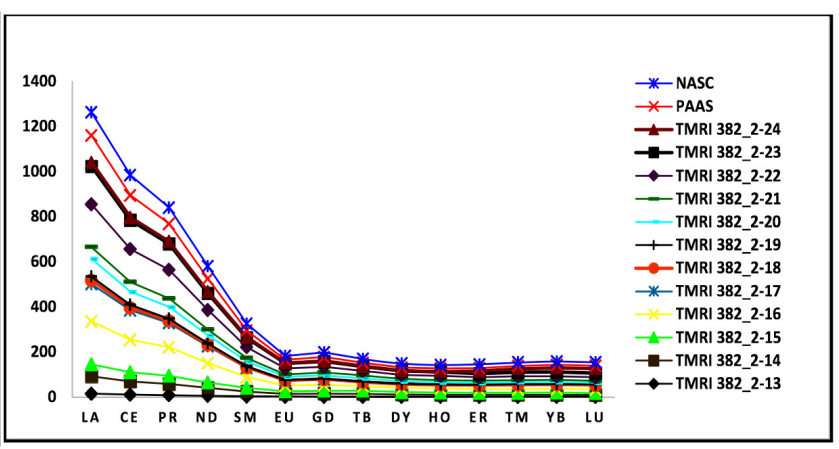

(B)

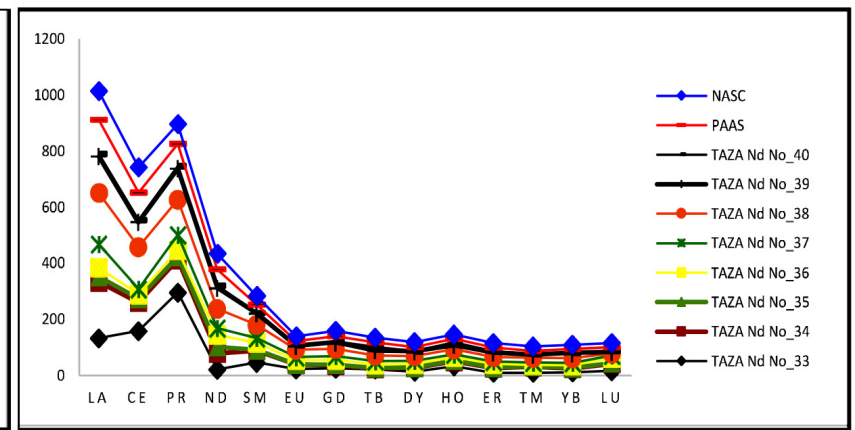

(D)

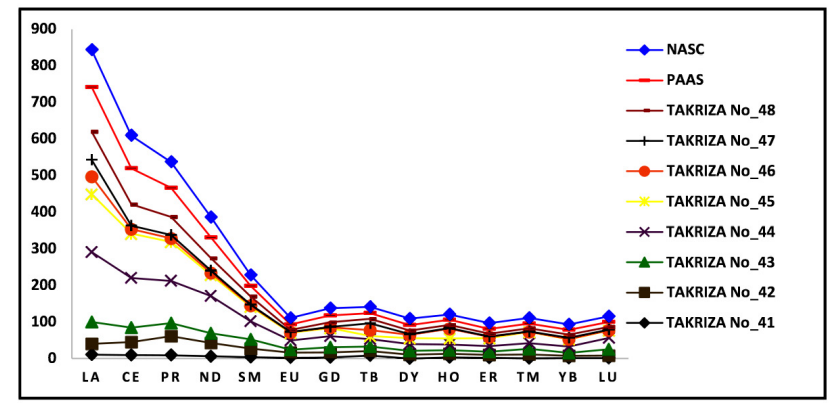

(E)

Figures 22. (A)-(E): Chondrite-normalized REE patterns of Tarat sandstones compared to the NASC and PAAS used as a reference; data are after [26].

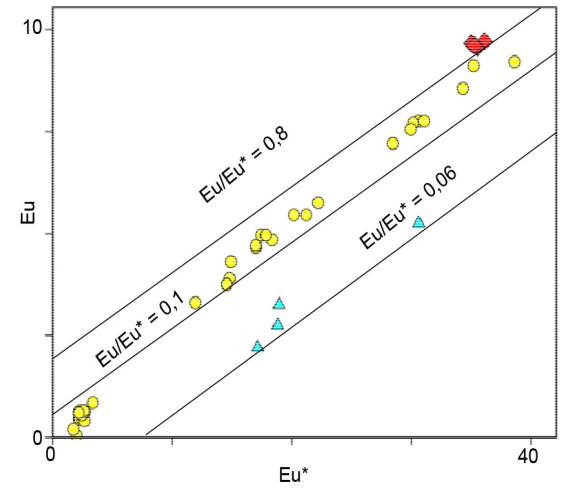

(A)

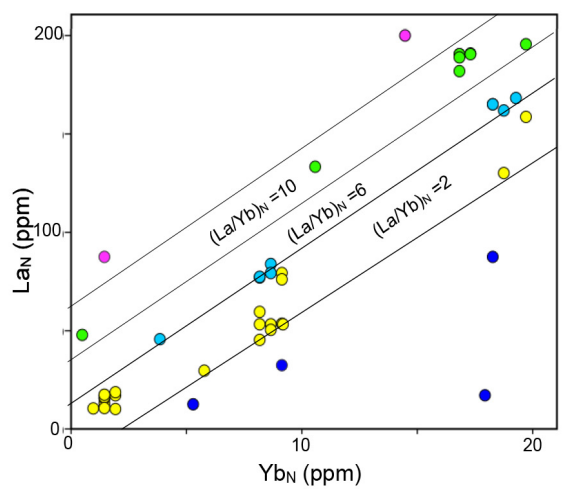

(B)

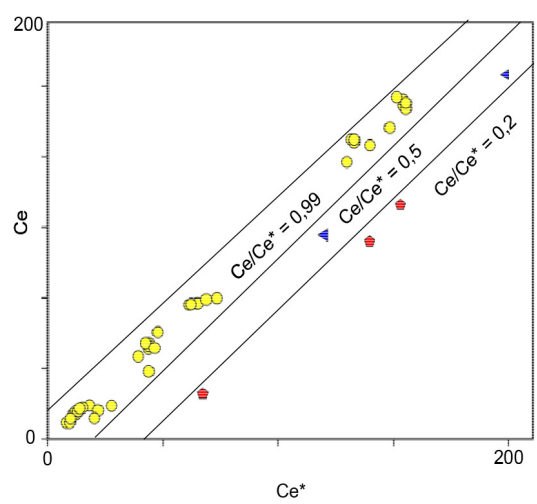

(C)

Figures 23. (A) Eu/Eu* anomaly; (B) $(\mathrm{La} / \mathrm{Yb})_{\mathrm{N}}$ ratio and (C) $\mathrm{Ce} / \mathrm{Ce}^{\star}$ anomaly. 


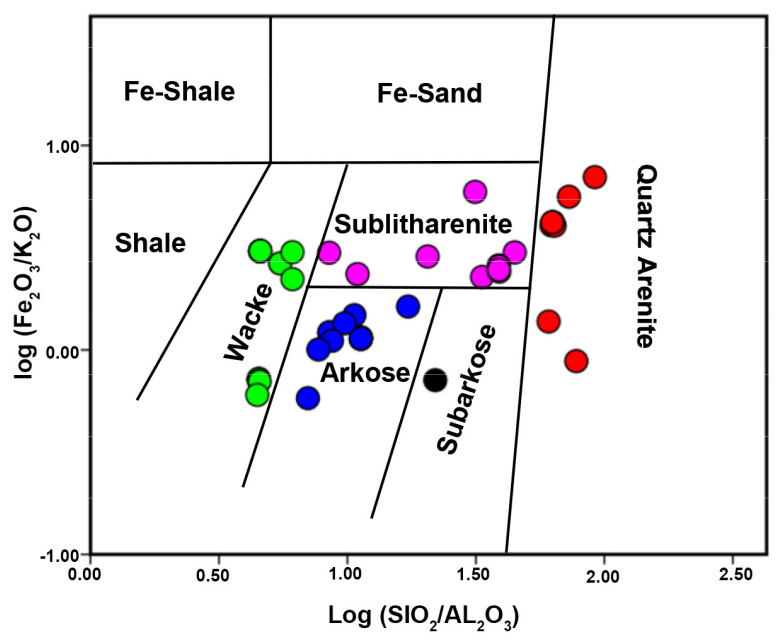

Figure 24. Geochemical classification of Tarat sandstones, using bivariate diagram $\log \left(\mathrm{Fe}_{2} \mathrm{O}_{3} / \mathrm{K}_{2} \mathrm{O}\right)$ versus $\log \left(\mathrm{SiO}_{2} / \mathrm{Al}_{2} \mathrm{O}_{3}\right)$ after [43].

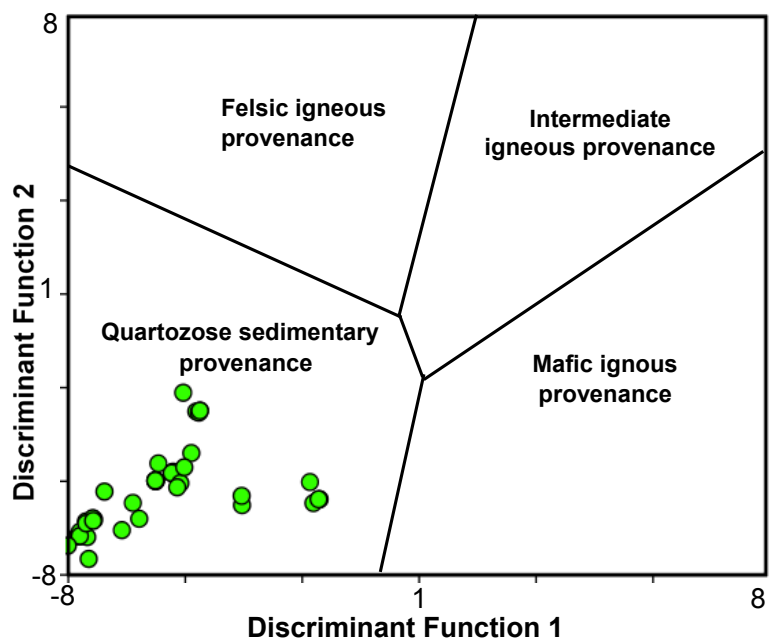

Figure 25. Provenance discrimination diagram for Tarat sandstones after [49].

\subsection{Source Area Weathering}

The authors in [6] [7] [8] [14] [15] [16] demonstrated that the Tarat sedimentary materials sourced from Air massif by weathering. The author in [50] noted that the weathering history of sedimentary rocks can be evaluated in part by examining relationships among the alkali and alkaline earth elements because alteration of igneous rocks during weathering results in depletion of alkali and alkaline earth elements and preferential enrichment of $\mathrm{Al}_{2} \mathrm{O}_{3}$ and $\mathrm{SiO}_{2}$ [61]. The most widely used indices for quantitative estimation of the degree of chemical weathering undergone by the rocks of the provenance area of sediments include: the Chemical Index of Alteration (CIA), Plagioclase index of Alteration (PIA) and Chemical Index of Weathering (CIW) proposed by [3] [62] [63] [64]. The 


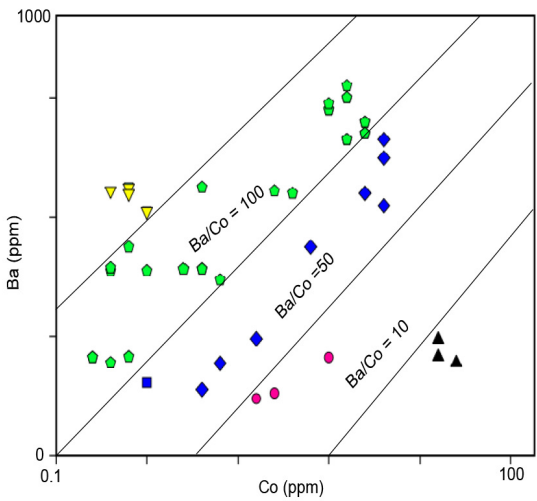

(A)

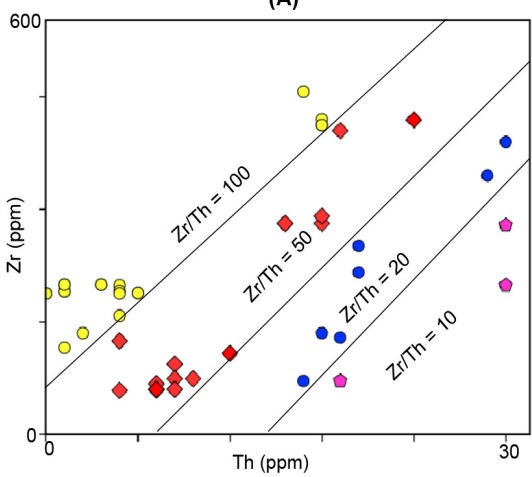

(D)

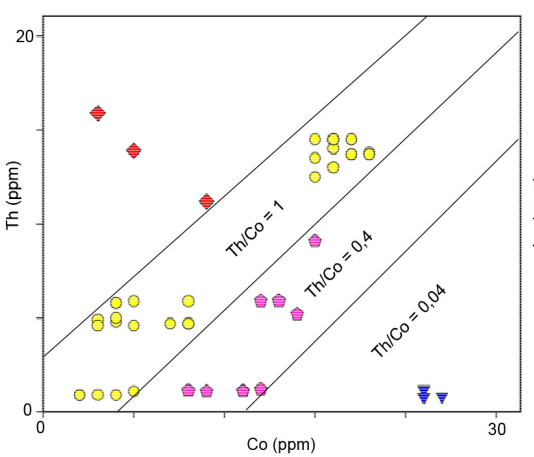

(G)

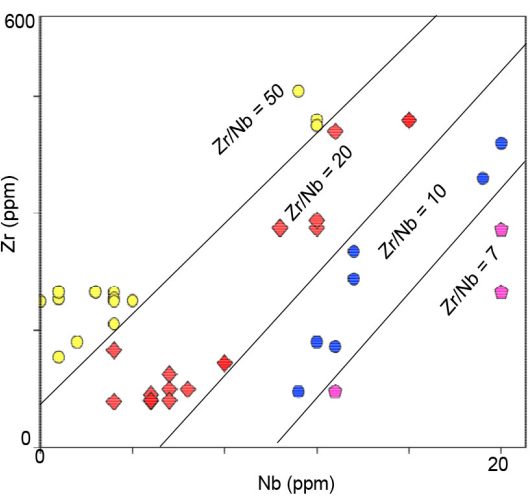

(B)

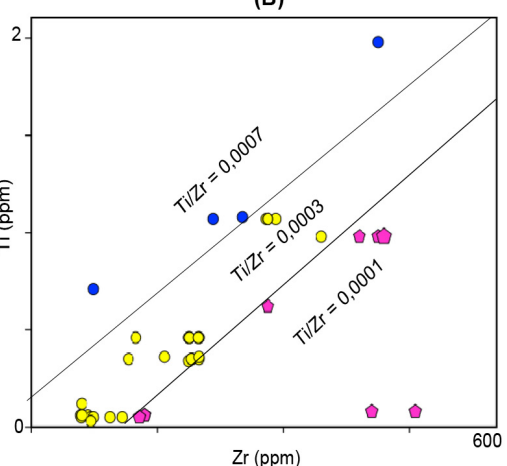

(E)

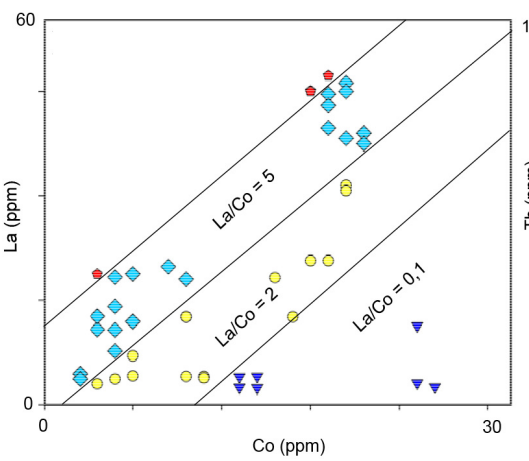

(H)

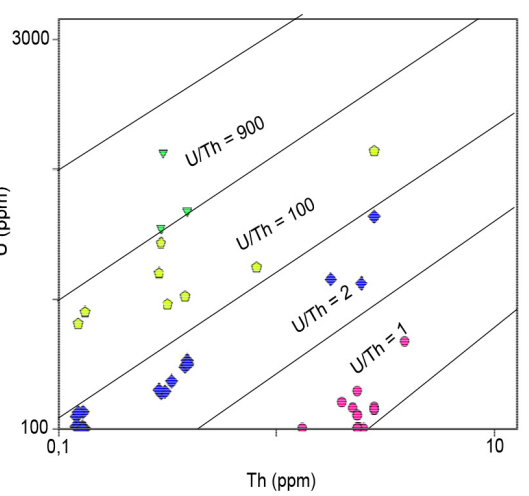

(C)

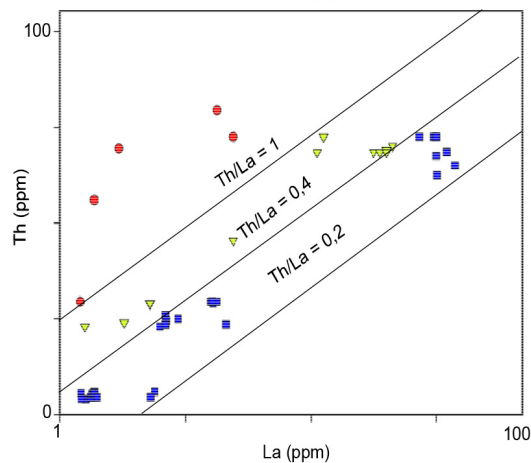

(F)

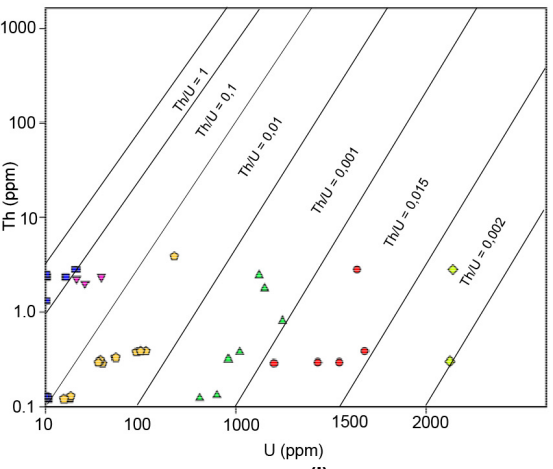

(I)

Figure 26. (A) Ba/Co ratio; (B) Zr/Nb ratio; (C) U/Th ratio; (D) Zr/Th ratio; (E) Ti/Zr ratio; (F) Th/La ratio; (G) La/Co ratio and (I) $\mathrm{Th} / \mathrm{U}$ ratio.

formula used to calculate the CIA, PIA and CIW are expressed below in molecular proportions:

$$
\begin{aligned}
& \mathrm{CIA}=\left[\mathrm{Al}_{2} \mathrm{O}_{3} /\left(\mathrm{Al}_{2} \mathrm{O}_{3}+\mathrm{CaO}^{*}+\mathrm{Na}_{2} \mathrm{O}+\mathrm{K}_{2} \mathrm{O}\right)\right] \times 100 \\
& \text { PIA }=\left[\left(\mathrm{Al}_{2} \mathrm{O}_{3}-\mathrm{K}_{2} \mathrm{O}\right) /\left(\mathrm{Al}_{2} \mathrm{O}_{3}+\mathrm{CaO}^{*}+\mathrm{Na}_{2} \mathrm{O}-\mathrm{K}_{2} \mathrm{O}\right] \times 100\right. \\
& \mathrm{CIW}=\left[\mathrm{Al}_{2} \mathrm{O}_{3} /\left(\mathrm{Al}_{2} \mathrm{O}_{3}+\mathrm{CaO}^{*}+\mathrm{Na}_{2} \mathrm{O}\right)\right] \times 100
\end{aligned}
$$

The $\mathrm{CaO}^{*}$ is defined as $\mathrm{CaO}$ in silicates fraction only. However, in the present study there was no formal way to distinguish carbonate $\mathrm{CaO}^{\star}$ from silicate $\mathrm{CaO}$, so the detected $\mathrm{CaO}$ is used here, therefore this can be justified base on the fact that none of the samples is calcareous and $\mathrm{CaO}$ is very low ranges from 0.04 to 


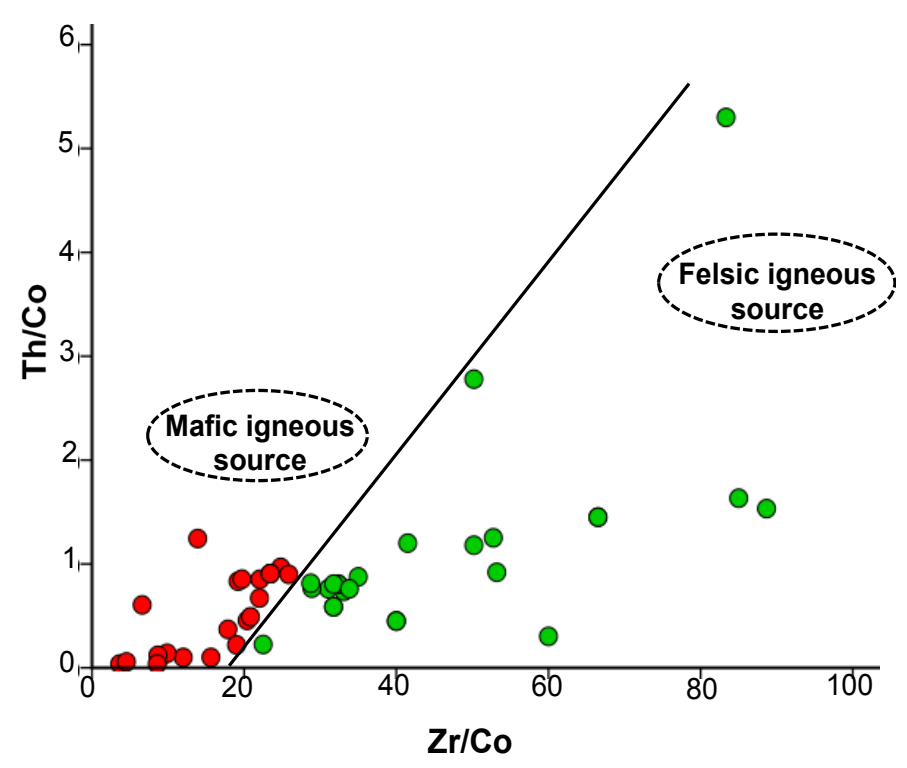

Figure 27. Th/Co vs. Zr/Co plot show felsic vs. mafic character [22].

0.29 with an average of 0.12 w.\% (Figure 14). High CIA and PIA values (75 $100)$ indicate intermediate to extreme weathering in the source area whereas low values ( $\leq 60)$ indicate low weathering in the source area [65] [66] [67].

From Figure 28, the CIA, PIA and CIW values of Tarat sandstones in the study area are mostly greater than $70 \%$, indicating intermediate to extreme weathering either at the source or during transport before deposition moreover, high CIA values, suggest derivation from a stable cratonic source [65] [68]. Also, the studied sandstones show very high PIA values from 93.33 to 97.68 (Figure 28) suggesting intense plagioclase weathering in the source area and resulted in low $\mathrm{CaO}$ content (Figure 14). This implies that with increasing chemical weathering the sediments are steadily depleted in plagioclases and enriched in secondary aluminous clay minerals [51] [69] [70].

Some elemental ratios such as $\mathrm{TiO}_{2} / \mathrm{Na}_{2} \mathrm{O}, \mathrm{K}_{2} \mathrm{O} / \mathrm{Na}_{2} \mathrm{O}, \mathrm{Al}_{2} \mathrm{O}_{3} / \mathrm{Na}_{2} \mathrm{O}$ and $\mathrm{Rb} / \mathrm{K}_{2} \mathrm{O}$ were used also as potential markers for intensities of chemical weathering [51]. These ratios progressively increase with increasing chemical weathering. Such case may be referred to the solubility and ion potential where labile cations $(\mathrm{Na}, \mathrm{K}, \mathrm{Ca}, \mathrm{Rb})$ are leached in favorite to insoluble hydrolysates $(\mathrm{Ti}, \mathrm{Al})$ [51] [59]. However, it is indicated that both $\mathrm{K}$ and $\mathrm{Rb}$ are integrated into clay minerals by adsorption and cation exchange during initial weathering of fresh rocks. But, with increasing weathering, $\mathrm{K}$ is preferentially leached compared to $\mathrm{Rb}$ [71]. Following the authors in [17] [51], plots of the present CIA values against $\mathrm{Al} / \mathrm{Na}, \mathrm{Al} / \mathrm{K}, \mathrm{Ti} / \mathrm{Na}, \mathrm{K} / \mathrm{Na}$ and $\mathrm{Rb} / \mathrm{K}$ elemental ratios support the intermediate to extreme chemical weathering (Figures 29(A)-(D) and Figure 29(F)).

The CIA data presented as a ternary plot of A-CN-K after [56] (Figure 29(B)), the Tarat sandstones plot mostly in upper part near smectite, chlorite and kaolinite 


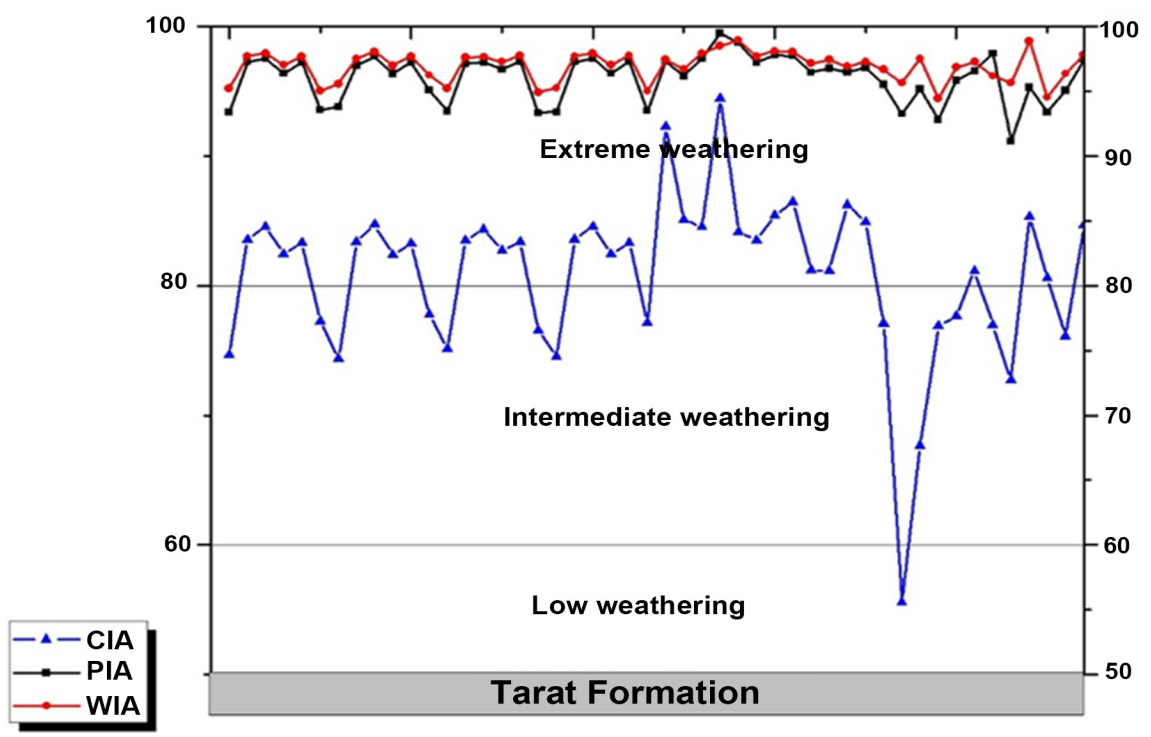

Figure 28. Geochemical profile of (CIA), (PIA) and (CIW) in Tarat sandstones.

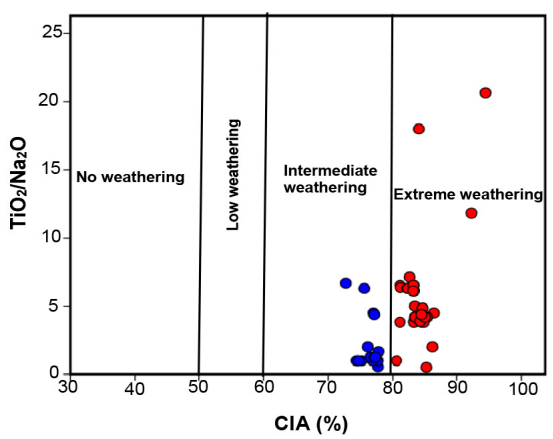

(A)

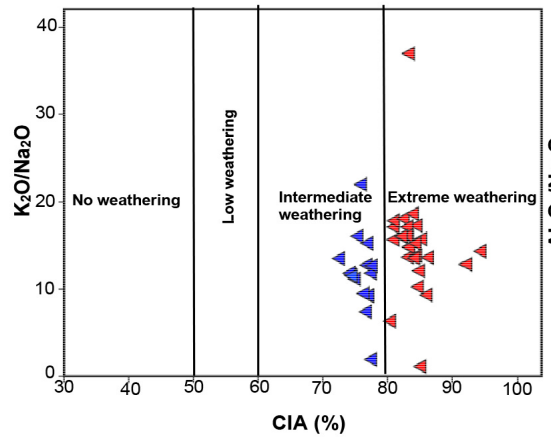

(B)

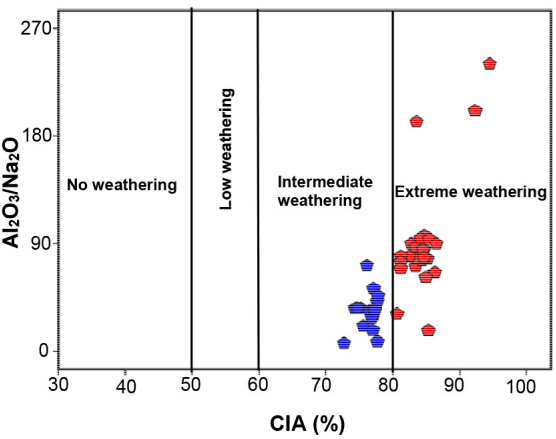

(C)
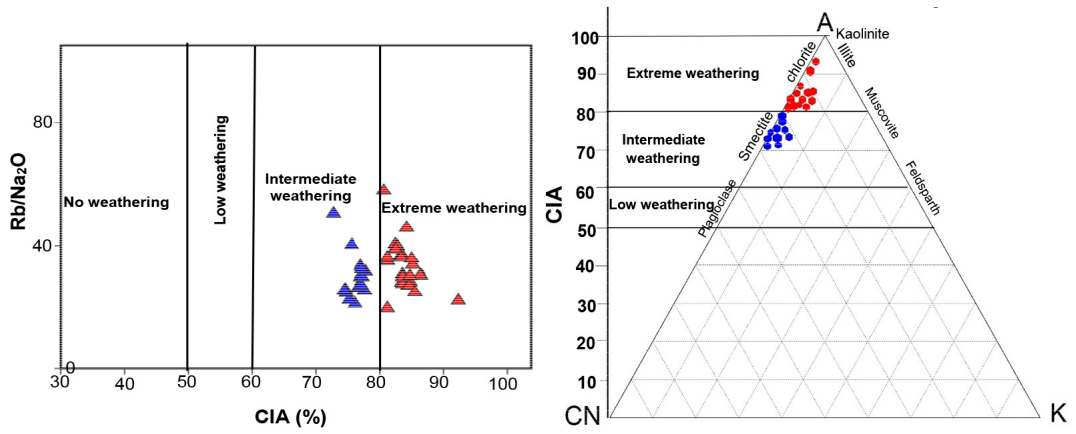

(D)

Figure 29. (A) $\mathrm{TiO}_{2} / \mathrm{Na}_{2} \mathrm{O}$ versus CIA; (B) $\mathrm{K}_{2} \mathrm{O} / \mathrm{Na}_{2} \mathrm{O}$ versus CIA; (C) $\mathrm{Al}_{2} \mathrm{O}_{3} / \mathrm{Na}_{2} \mathrm{O}$ versus CIA; (D) $\mathrm{Rb} / \mathrm{Na}_{2} \mathrm{O}$ versus CIA and (D) A-CN-K diagram for Tarat sandstone, $\mathrm{A}: \mathrm{Al}_{2} \mathrm{O}_{3}, \mathrm{C}: \mathrm{CaO}, \mathrm{K}: \mathrm{K}_{2} \mathrm{O}$ after [56].

with intermediate to extreme weathering conditions.

\subsection{Paleo-Redox Condition}

A function climate diagram was used in order to identify the depositional environmental climatic conditions of Tarat sandstones after [72]. The plotted sam- 
ples revealed Arid to humid environmental conditions with high chemical maturity (Figure 30). In order to infer the paleo-oxygenation condition of the Tarat formation the U/Th ratio has been used as a redox indicator [4] [73] [74] [75]. A $\mathrm{U} / \mathrm{Th}$ ratio below 1.25 suggests oxic deposition conditions whereas values above 1.25 suggest suboxic and anoxic conditions [4] [26] [73] [75] [76]. In this study, the Tarat samples had high U/Th $>1.25$ ratios (Figure 26(C)), indicating that the studied samples were deposited in an anoxic environment. Moreover, the $\mathrm{Th} / \mathrm{U}$ ratios have been used to evaluate the uranium enrichment of Tarat formation compared to the crust average compositions. According to [16] the Th/U > 4 indicates uranium depletion over the crust composition while $\mathrm{Th} / \mathrm{U}<3$ indicates the uranium enrichment over the crust average composition. The present study indicates that Tarat samples had $\mathrm{Th} / \mathrm{U}<3$ (Figure 26(I)) suggesting high uranium enrichment.

\subsection{Tectonic Setting}

The authors in [20] [49] [77] [78] [79] demonstrated that the chemical compositions of sedimentary rocks are significantly controlled by plate tectonic settings of their provenances depositional basins and introduced a discrimination diagram utilizing $\mathrm{K}_{2} \mathrm{O} / \mathrm{Na}_{2} \mathrm{O}$ versus $\mathrm{SiO}_{2}$ to determine the tectonic setting of terrigenous sedimentary rocks. The plot $\mathrm{K}_{2} \mathrm{O} / \mathrm{Na}_{2} \mathrm{O}$ versus $\mathrm{SiO}_{2}$ for the study samples (Figure 31(A), and Figure 31(B)) implies that they are typical of sediments deposited in a passive margin setting. According to the authors in [49] passive margin sediments are largely quartz-rich sediments derived from plate interiors or stable continental areas and deposited in intracratonic basins or on passive continental margins.

\subsection{Uranium Mineralization and Associated Elements}

The purpose of using factor analysis of geochemical data in this research is to group the elements associated or not with uranium and those representing the detrital fraction. Furthermore, the correlational analysis was used to determine the genesis of uranium mineralization. As such, we classified the samples into two groups according to their uranium contents:

- Samples with $\mathrm{U}<100$ ppm and;

- Samples with $\mathrm{U}>100$ ppm.

\subsubsection{Samples with $U<100$ ppm}

The factor analysis results of samples with $\mathrm{U}<100 \mathrm{ppm}$ are represented in the three-dimensional spatial diagram and reflect the distribution of the elements in three factors after rotation (Figure 32). Three factors selected in this analysis express $86.87 \%$ of the total variance divide as such factor 1 (71.87\%), factor (8.67\%) and factor 3 (6.33\%). In order to visualize and distinguish the different poles, two factors 1 and 2 have been used since they formed to $80.54 \%$ of the total variance. The two-dimensional spatial diagram of factors 1 and 2 distinguished several poles (Figure 33): 


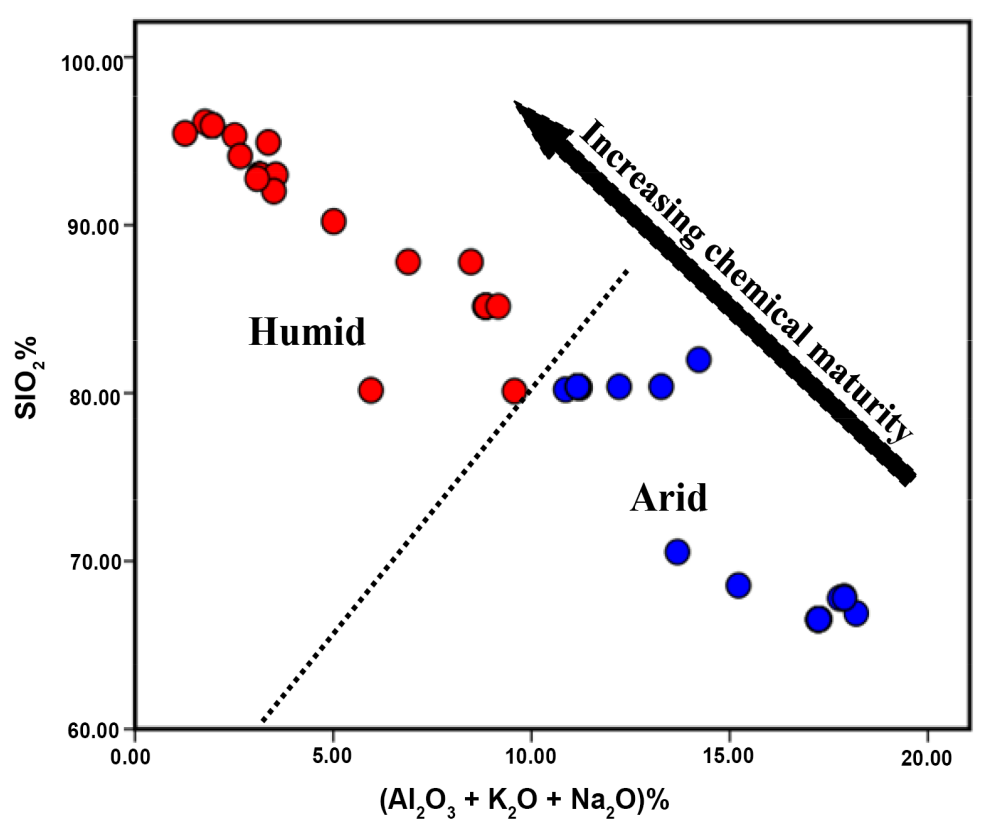

Figure 30. Depositional environmental climatic conditions of Tarat sandstones based on $\mathrm{SiO}_{2}$ wt. \% versus $\left(\mathrm{Al}_{2} \mathrm{O}_{3}+\mathrm{K}_{2} \mathrm{O}+\mathrm{Na}_{2} \mathrm{O}\right)$ wt. $\%$ bivariate diagram after [72].

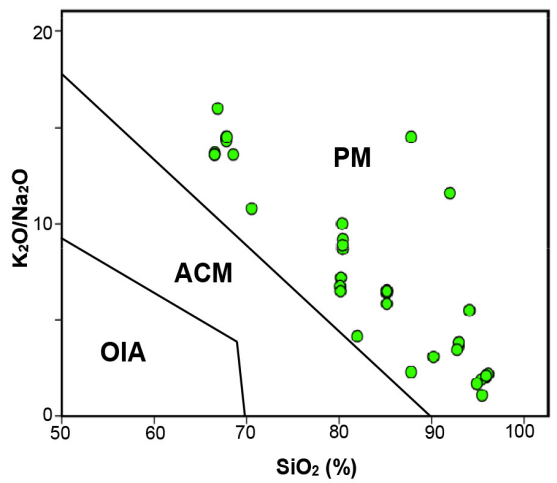

(A)

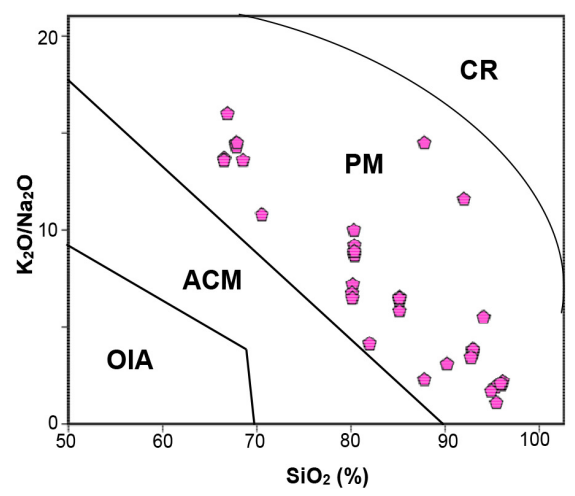

(B)

Figure 31. (a) $\mathrm{SiO}_{2}$ wt.\% versus $\mathrm{K}_{2} \mathrm{O} / \mathrm{Na}_{2} \mathrm{O}$ diagram: $\mathrm{ACM}=$ Active Continental Margin, OIA = Oceanic Island Arc and $\mathrm{PM}=$ Passive Margin [49]. (b) $\mathrm{SiO}_{2}$ wt.\% versus $\mathrm{K}_{2} \mathrm{O} / \mathrm{Na}_{2} \mathrm{O}$ diagram: $\mathrm{CR}=$ Continental Rift, $\mathrm{ACM}=$ Active Continental Margin, $\mathrm{PM}=$ Passive Margin and ARC [49].

* The siliceous $\mathrm{SiO}_{2}$ pole which corresponds mineralogically to the fraction of detrital grains of quartz;

* Uraniferous pole including $\mathrm{U}, \mathrm{Mo}$ and $\mathrm{Pb}$ close and distinct to the organic pole but anticorrelated to the siliceous pole. The uraniferous pole extends towards the siliceous pole suggesting double sources of these elements such as detrital provenance and precipitation with mineralization;

* Pole controlled by organic matter (C\%) associated with $\mathrm{Be}, \mathrm{MnO}, \mathrm{Ga}, \mathrm{Sn}, \mathrm{Nb}$ and Co; 


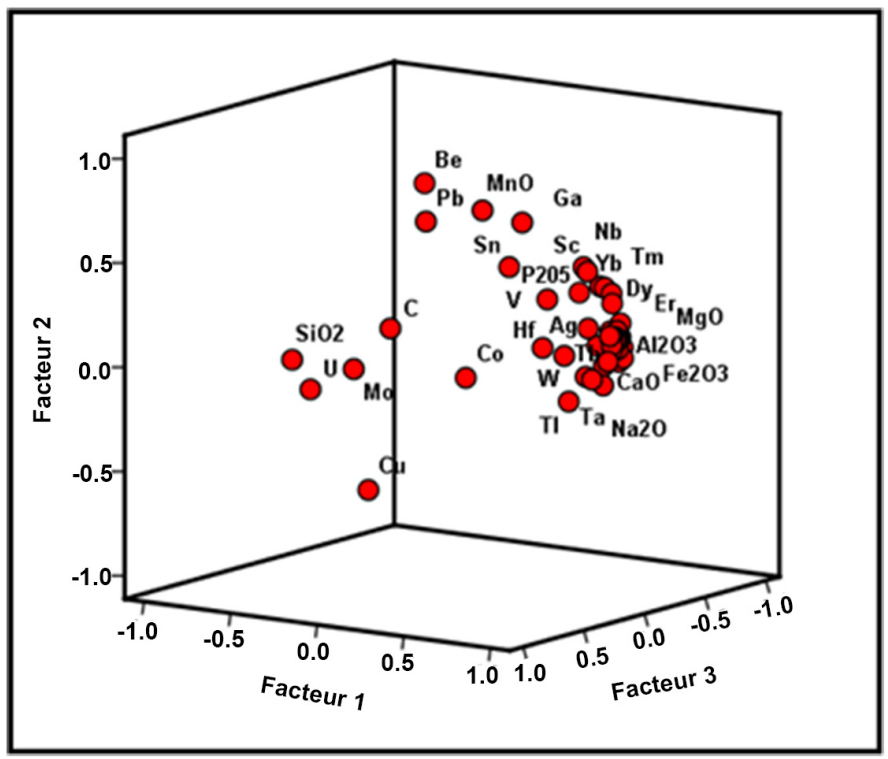

Figure 32. 3D spatial diagram plot of factors 1, 2 and 3 of samples with $\mathrm{U}<100$ ppm.

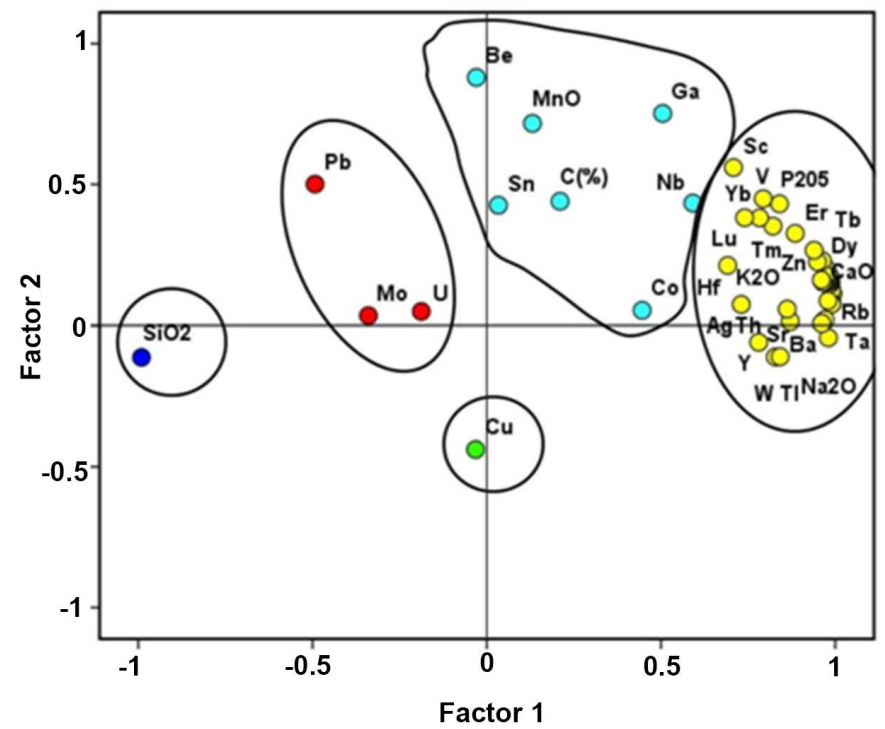

Figure 33. 2D spatial diagram of factors 1 and 2 of samples with $U<$ $100 \mathrm{ppm}$.

* Pole composed of the following elements: $\mathrm{Ba}, \mathrm{Sr}, \mathrm{K}_{2} \mathrm{O}, \mathrm{Ti}, \mathrm{W}, \mathrm{Na}_{2} \mathrm{O}, \mathrm{Nb}$, $\mathrm{Al}_{2} \mathrm{O}_{3}, \mathrm{Sc}, \mathrm{V}, \mathrm{Yb}, \mathrm{Co}, \mathrm{Ag}$, Th, Hf, Er, $\mathrm{P}_{2} \mathrm{O}_{5}, \mathrm{Tm}, \mathrm{Tb}, \mathrm{Zn}, \mathrm{Gd}, \mathrm{TiO}_{2}, \mathrm{CaO}, \mathrm{Rb}$, $\mathrm{Ni}, \mathrm{Zr}$ and $\mathrm{Fe}_{2} \mathrm{O}_{3}$ essentially corresponding to detrital minerals (feldspar and clays); iron-titanium oxides, and accessory minerals of monazite and zircon;

* Cu did not define a particular position.

\subsubsection{Correlation Relationship between $\mathrm{U}<100 \mathrm{ppm}$ and Major 0xides} From Table 1, uranium defines a negative correlation with all the major oxides. These relationships may be explained by three mechanisms: 1) uranium 
Table 1. Results of correlation analysis between $U<100$ ppm and major oxides of Tarat samples.

\begin{tabular}{|c|c|c|c|c|c|c|c|c|c|c|c|}
\hline Coef. & $\mathrm{SiO}_{2}$ & $\mathrm{Al}_{2} \mathrm{O}_{3}$ & $\mathrm{Fe}_{2} \mathrm{O}_{3}$ & $\mathrm{MnO}$ & $\mathrm{MgO}$ & $\mathrm{CaO}$ & $\mathrm{Na}_{2} \mathrm{O}$ & $\mathrm{K}_{2} \mathrm{O}$ & $\mathrm{TiO}_{2}$ & $\mathrm{P}_{2} \mathrm{O}_{5}$ & $\mathrm{U}$ \\
\hline $\mathrm{SiO}_{2}$ & 1 & & & & & & & & & & \\
\hline $\mathrm{Al}_{2} \mathrm{O}_{3}$ & $\underline{-0.99}$ & 1 & & & & & & & & & \\
\hline $\mathrm{Fe}_{2} \mathrm{O}_{3}$ & $\underline{-0.99}$ & 0.99 & 1 & & & & & & & & \\
\hline $\mathrm{MnO}$ & $\underline{-0.22}$ & 0.25 & 0.19 & 1 & & & & & & & \\
\hline $\mathrm{MgO}$ & -0.99 & 0.99 & 0.99 & 0.25 & 1 & & & & & & \\
\hline $\mathrm{CaO}$ & -0.99 & 0.98 & 0.99 & 0.22 & 0.97 & 1 & & & & & \\
\hline $\mathrm{Na}_{2} \mathrm{O}$ & -0.97 & 0.96 & 0.96 & 0.03 & 0.95 & 0.96 & 1 & & & & \\
\hline $\mathrm{K}_{2} \mathrm{O}$ & $\underline{-0.99}$ & 0.99 & 0.99 & 0.19 & 0.98 & 0.98 & 0.98 & 1 & & & \\
\hline $\mathrm{TiO}_{2}$ & $\underline{-0.99}$ & 0.99 & 0.99 & 0.24 & 0.99 & 0.98 & 0.95 & 0.99 & 1 & & \\
\hline $\mathrm{P}_{2} \mathrm{O}_{5}$ & $\underline{-0.89}$ & 0.9 & 0.87 & 0.6 & 0.91 & 0.86 & 0.79 & 0.88 & 0.89 & 1 & \\
\hline $\mathrm{U}$ & -0.14 & -0.14 & $\underline{-0.17}$ & $\underline{-0.17}$ & --0.13 & $\underline{-0.24}$ & -0.04 & $\underline{-0.1}$ & $\underline{-0.18}$ & -0.06 & 1 \\
\hline
\end{tabular}

mineralization is associated with a strong depletion of major oxides in the host rocks; 2) mineralization is only associated with lithologies that were depleted of major oxides before mineralization; and 3) uranium mineralization lower than $100 \mathrm{ppm}$ only occurs in altered horst environment depleted of major oxides. The third mechanism may explain the strong positive correlations between all major oxides except $\mathrm{SiO}_{2}$ indicating the similar geochemical behavior of these elements during weathering. The negative correlation of $\mathrm{SiO}_{2}$ with all major oxides reflects the "dilution effect" of quartz in Tarat formation. It is difficult to differentiate the first and second mechanism, but both may have contributed to the observed negative correlation between uranium and the major oxides, either by the depletion of the major element or by the argilisation phenomenon syn or post mineralization.

\subsubsection{Correlation Relationship between $U<100 \mathrm{ppm}$ and Trace Elements}

There is negative correlation between $\mathrm{U}, \mathrm{V}, \mathrm{Co}, \mathrm{Cu}, \mathrm{Mo}$ and $\mathrm{Pb}$ (Table 2) that reflects close affiliation of uranium minerals to feldspar minerals, barytine and zircon or common origin and similar geochemical composition of these elements. Moreover, Mo- $\mathrm{U}$ defines the same pole with strong positive correlation ( $\mathrm{r}$ $=0.81)$. In addition, $\mathrm{U}-\mathrm{Cu}$ has positive relationship $(\mathrm{r}=0.57)$. Based on $\mathrm{U}-\mathrm{Mo}$ and $\mathrm{U}-\mathrm{Cu}$ positive correlations, the uranium mineralization of Tarat formation originated from synsedimentary volcanic source. This is evident from world largest U-Mo mineralization of Steltsovka (Russia) deposited just deposited after volcanic activity [80] and U-Momineralization of the western part of the Xiangshan caldera (China) [81]. The lack of positive correlation between U-Th our studied samples are the result of remobilization of $U$ [6] [81]. 
Table 2. Results of correlation analysis between $U<100 \mathrm{ppm}$ and trace elements of Tarat samples.

\begin{tabular}{|c|c|c|c|c|c|c|c|c|c|c|c|c|c|c|}
\hline Coef & $\mathrm{V}$ & $\mathrm{Cr}$ & Co & $\mathrm{Ni}$ & $\mathrm{Cu}$ & $\mathrm{Zn}$ & As & $\mathrm{Zr}$ & Mo & $\mathrm{Ag}$ & $\mathrm{Ba}$ & $\mathrm{Pb}$ & Th & $\mathrm{U}$ \\
\hline $\mathrm{V}$ & 1 & & & & & & & & & & & & & \\
\hline $\mathrm{Cr}$ & 0.85 & 1 & & & & & & & & & & & & \\
\hline Co & 0.54 & 0.44 & 1 & & & & & & & & & & & \\
\hline $\mathrm{Ni}$ & 0.85 & 0.99 & 0.44 & 1 & & & & & & & & & & \\
\hline $\mathrm{Cu}$ & 0.01 & -0.06 & 0.29 & -0.11 & 1 & & & & & & & & & \\
\hline $\mathrm{Zn}$ & 0.85 & 0.97 & 0.49 & 0.98 & -0.11 & 1 & & & & & & & & \\
\hline As & 0.83 & 0.95 & 0.30 & 0.97 & -0.16 & 0.91 & 1 & & & & & & & \\
\hline $\mathrm{Zr}$ & 0.80 & 0.97 & 0.50 & 0.98 & -0.12 & 0.97 & 0.93 & 1 & & & & & & \\
\hline Mo & -0.03 & -0.31 & 0.44 & -0.32 & 0.55 & -0.22 & -0.42 & -0.34 & 1 & & & & & \\
\hline $\mathrm{Ag}$ & 0.66 & 0.81 & 0.33 & 0.74 & 0.21 & 0.72 & 0.71 & 0.72 & -0.26 & 1 & & & & \\
\hline $\mathrm{Ba}$ & 0.77 & 0.95 & 0.43 & 0.96 & -0.13 & 0.94 & 0.93 & 0.96 & -0.31 & 0.74 & 1 & & & \\
\hline $\mathrm{Pb}$ & -0.39 & -0.38 & -0.39 & -0.39 & -0.75 & -0.31 & -0.37 & -0.38 & -0.18 & -0.37 & -0.37 & 1 & & \\
\hline Th & 0.68 & 0.87 & 0.35 & 0.87 & -0.27 & 0.86 & 0.84 & 0.86 & -0.28 & 0.63 & 0.95 & -0.20 & 1 & \\
\hline $\mathrm{U}$ & 0.19 & -0.18 & 0.50 & -0.19 & 0.57 & -0.18 & -0.19 & -0.23 & 0.81 & -0.09 & -0.21 & 0.76 & -0.25 & 1 \\
\hline
\end{tabular}

\section{1) Correlation relationship between $U<100 \mathrm{ppm}$ and REE}

There is a negative correlation between $\mathrm{U}$ and REE except of $\mathrm{Tb}(\mathrm{r}=0.03)$ (Table 3). The positive correlation between $\mathrm{U}$ and $\mathrm{Tb}$ indicates the similar geochemical composition of these elements during mineralization.

\subsubsection{Samples with $U>100 \mathrm{ppm}$}

The results of factor of samples with $U>100 \mathrm{ppm}$ are represented in the three-dimensional spatial diagram and reflect the distribution of the elements in three factors after rotation (Figure 34). Three factors selected in this analysis expressed a total variance of $86.87 \%$, as such factor 1 (56.99\%), factor $2(9.14 \%)$ and factor $3(4.43 \%)$. For more visualization of poles two factors 1 and 2 that have $60.46 \%$ of the total variance was used. The two-dimensional spatial diagram of factors 1 and 2 distinguished several poles (Figure 35):

* Siliceous $\mathrm{SiO}_{2}$ pole representing mineralogically detrital fraction of quartz grains;

* Uranium mineralization pole composed of $\mathrm{U}, \mathrm{Zn}, \mathrm{Ni}$ and $\mathrm{Pb}$ close to the organic pole and anticorrelated to the siliceous pole. The uraniferous pole extends towards the siliceous pole suggesting double sources of these elements: detrital provenance and precipitation with mineralization;

- Pole governed by the organic matter (C\%) and associated with Ho, Co, Sn, $\mathrm{As}, \mathrm{CaO}, \mathrm{Nb}, \mathrm{Sc}, \mathrm{Mo}$;

* Pole composed of $\mathrm{Fe}_{2} \mathrm{O}_{3}$ and $\mathrm{MnO}$; 
Table 3. Results of correlation analysis between $\mathrm{U}<100$ ppm and REE.

\begin{tabular}{cccccccccccccccc}
\hline Coef & $\mathrm{La}$ & $\mathrm{C}$ & $\mathrm{Pr}$ & $\mathrm{Nd}$ & $\mathrm{Sm}$ & $\mathrm{Eu}$ & $\mathrm{Gd}$ & $\mathrm{Tb}$ & $\mathrm{Dy}$ & $\mathrm{Ho}$ & $\mathrm{Er}$ & $\mathrm{Tm}$ & $\mathrm{Yb}$ & $\mathrm{Lu}$ & $\mathrm{U}$ \\
\hline $\mathrm{La}$ & 1 & & & & & & & & & & & & & \\
$\mathrm{Ce}$ & 0.99 & 1 & & & & & & & & & & & & \\
$\mathrm{Pr}$ & 0.99 & 0.99 & 1 & & & & & & & & & & & \\
$\mathrm{Nd}$ & 0.99 & 0.99 & 0.99 & 1 & & & & & & & & & & \\
$\mathrm{Sm}$ & 0.99 & 0.99 & 0.99 & 0.99 & 1 & & & & & & & & \\
$\mathrm{Eu}$ & 0.99 & 0.99 & 0.99 & 0.99 & 0.99 & 1 & & & & & & & \\
$\mathrm{Gd}$ & 0.99 & 0.99 & 0.99 & 0.99 & 0.99 & 0.99 & 1 & & & & & & & \\
$\mathrm{~Tb}$ & 0.96 & 0.96 & 0.97 & 0.97 & 0.97 & 0.97 & 0.97 & 1 & & & & & & \\
$\mathrm{Dy}$ & 0.99 & 0.99 & 0.99 & 0.99 & 0.99 & 0.99 & 0.99 & 0.95 & 1 & & & & & \\
$\mathrm{Ho}$ & 0.99 & 0.99 & 0.99 & 0.99 & 0.99 & 0.99 & 0.99 & 0.98 & 0.98 & 1 & & & & \\
$\mathrm{Er}$ & 0.93 & 0.93 & 0.93 & 0.93 & 0.93 & 0.93 & 0.93 & 0.9 & 0.92 & 0.93 & 1 & & & \\
$\mathrm{Tm}$ & 0.89 & 0.89 & 0.88 & 0.89 & 0.89 & 0.89 & 0.88 & 0.84 & 0.88 & 0.88 & 0.99 & 1 & & \\
$\mathrm{Yb}$ & 0.86 & 0.86 & 0.85 & 0.86 & 0.86 & 0.86 & 0.85 & 0.81 & 0.84 & 0.85 & 0.98 & 0.99 & 1 & & \\
$\mathrm{Lu}$ & 0.82 & 0.82 & 0.81 & 0.82 & 0.82 & 0.82 & 0.82 & 0.78 & 0.8 & 0.81 & 0.96 & 0.99 & 0.99 & 1 \\
$\mathrm{U}$ & $\underline{-0.18}$ & $\underline{-0.18}$ & $\underline{-0.18}$ & $\underline{-0.17}$ & $\underline{-0.15}$ & $\underline{-0.914}$ & $\underline{-0.14}$ & 0.03 & $\underline{-0.23}$ & $\underline{-0.11}$ & $\underline{-0.2}$ & $\underline{-0.26}$ & $\underline{-0.23}$ & $\underline{-0.23}$ & 1 \\
\hline
\end{tabular}

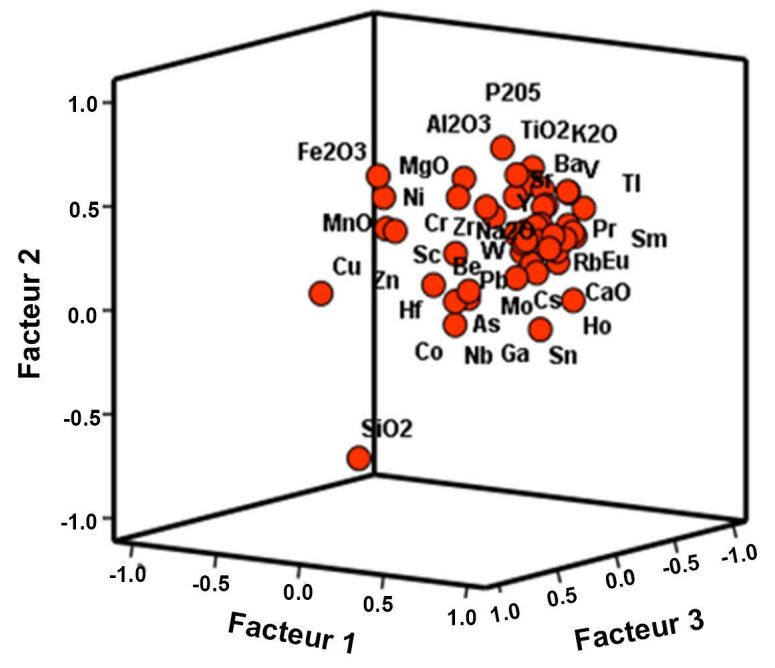

Figure 34. 3D spatial diagram plot of factors 1, 2 and 3 of samples with $\mathrm{U}>100 \mathrm{ppm}$.

Pole composed of the following elements: $\mathrm{Ga}$, Dy, Ce, Sm, Gd, Eu, Rb, Pr, Tb, $\mathrm{Nd}, \mathrm{Y}$, Th, La, Cs, Tm, Er, Zr, Lu, Ta, Be, Sr, Ba, V, TI, Ta, $\mathrm{P}_{2} \mathrm{O}_{5}, \mathrm{Cr}, \mathrm{MgO}, \mathrm{Ag}$, $\mathrm{K}_{2} \mathrm{O}, \mathrm{TiO}_{2}, \mathrm{Al}_{2} \mathrm{O}_{3}$ and $\mathrm{W}$. This pole corresponds essentially to iron-titanium oxides, monazite accessory minerals, and clays;

$\mathrm{Cu}$ and $\mathrm{Hf}$ did not define specific positions. 


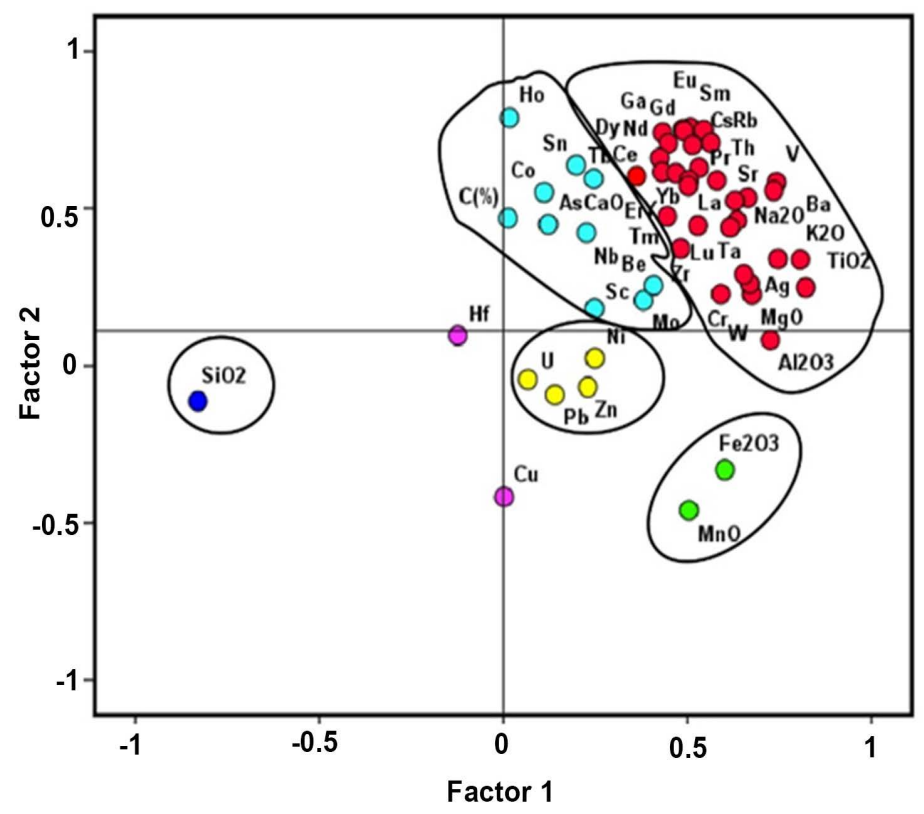

Figure 35. 2D spatial diagram of factors 1 and 2 of samples with $U>$ $100 \mathrm{ppm}$.

\section{1) Correlation relationship between $U>100 \mathrm{ppm}$ and major oxides}

There is a weak positive correlation between $\mathrm{SiO}_{2}, \mathrm{Al}_{2} \mathrm{O}_{3}, \mathrm{MnO}, \mathrm{MgO}$ and $\mathrm{U}$ (Table 4) reflects the similar geochemical composition of these elements during the mineralization process. However, there is a negative correlation of $U$ with $\mathrm{F}_{2} \mathrm{O}_{3}, \mathrm{CaO}, \mathrm{Na}_{2} \mathrm{O}, \mathrm{K}_{2} \mathrm{O}, \mathrm{TiO}_{2}$ and $\mathrm{P}_{2} \mathrm{O}_{5}$ (Table 4) suggests a close affiliation of uranium minerals to clay minerals, titanium, and potassium. The negative relationship of $\mathrm{U}$ and $\mathrm{F}_{2} \mathrm{O}_{3}(\mathrm{r}=-0.23)$ indicates the less oxidizing depositional environment of Tarat samples. The similar negative relationship of $\mathrm{CaO}, \mathrm{P}_{2} \mathrm{O}_{5}$ and $\mathrm{U}$ (Table 4) is essentially related to either low $\mathrm{CaO}$ or $\mathrm{P}_{2} \mathrm{O}_{5}$ concentrations associated with high $\mathrm{U}$ content affected by the pre-weathering phenomenon or attributed to the "dilution effect" of the mineralization.

\section{2) Correlation relationship between $U>100 \mathrm{ppm}$ and trace elements}

From Table 5, there is a negative correlation between $\mathrm{U}, \mathrm{V}, \mathrm{Co}, \mathrm{Cu}, \mathrm{Zn}, \mathrm{Mo}$ and $\mathrm{Pb}$ reflecting close affiliation of uranium minerals to feldspar minerals, barytine and zircon or common origin and similar geochemical composition of these elements. Moreover, there is positive correlation between $\mathrm{U}, \mathrm{Mo}$ and $\mathrm{Cu}(\mathrm{r}$ $=0.81 ; \mathrm{r}=55)$. These relationships suggest the volcanicsynsedimentary origin of these elements.

\section{3) Correlation relationship between $U>100 \mathrm{ppm}$ and REE}

There is a positive correlation between $U$ and LREE (Table 6). This relationship suggests similar geochemical composition of these elements and preservation of heavy minerals. However, we noted negative correlation between $U$ and HREE. The relationship of $U$ and REE suggests that these elements ensure the control of uranium mineralization distribution during weathering. 
Table 4. Results of correlation analysis between $U>100$ ppm and major oxides of Tarat samples.

\begin{tabular}{|c|c|c|c|c|c|c|c|c|c|c|c|}
\hline Coef & $\mathrm{SiO}_{2}$ & $\mathrm{Al}_{2} \mathrm{O}_{3}$ & $\mathrm{Fe}_{2} \mathrm{O}_{3}$ & $\mathrm{MnO}$ & $\mathrm{MgO}$ & $\mathrm{CaO}$ & $\mathrm{Na}_{2} \mathrm{O}$ & $\mathrm{K}_{2} \mathrm{O}$ & $\mathrm{TiO}_{2}$ & $\mathrm{P}_{2} \mathrm{O}_{5}$ & $\mathrm{U}$ \\
\hline $\mathrm{SiO}_{2}$ & 1 & & & & & & & & & & \\
\hline $\mathrm{Al}_{2} \mathrm{O}_{3}$ & $\underline{-0.93}$ & 1 & & & & & & & & & \\
\hline $\mathrm{Fe}_{2} \mathrm{O}_{3}$ & -0.46 & 0.29 & 1 & & & & & & & & \\
\hline $\mathrm{MnO}$ & -0.2 & 0.16 & 0.49 & 1 & & & & & & & \\
\hline $\mathrm{MgO}$ & $\underline{-0.58}$ & 0.48 & 0.59 & 0.23 & 1 & & & & & & \\
\hline $\mathrm{CaO}$ & -0.49 & 0.49 & 0.05 & $\underline{-0.23}$ & 0.18 & 1 & & & & & \\
\hline $\mathrm{Na}_{2} \mathrm{O}$ & -0.54 & 0.43 & 0.24 & 0.02 & 0.35 & 0.77 & 1 & & & & \\
\hline $\mathrm{K}_{2} \mathrm{O}$ & -0.82 & 0.69 & 0.36 & 0.09 & 0.54 & 0.63 & 0.74 & 1 & & & \\
\hline $\mathrm{TiO}_{2}$ & $\underline{-0.72}$ & 0.61 & 0.56 & 0.5 & 0.68 & 0.45 & 0.55 & 0.78 & 1 & & \\
\hline $\mathrm{P}_{2} \mathrm{O}_{5}$ & -0.47 & 0.37 & 0.52 & 0.21 & 0.53 & 0.49 & 0.65 & 0.5 & 0.56 & 1 & \\
\hline $\mathrm{U}$ & -0.01 & 0.03 & $\underline{-0.23}$ & 0.04 & 0.06 & $\underline{-0.11}$ & $\underline{-0.18}$ & $\underline{-0.09}$ & $\underline{-0.09}$ & $\underline{-0.11}$ & 1 \\
\hline
\end{tabular}

Table 5. Results of correlation analysis between $\mathrm{U}>100 \mathrm{ppm}$ and trace elements of Tarat samples.

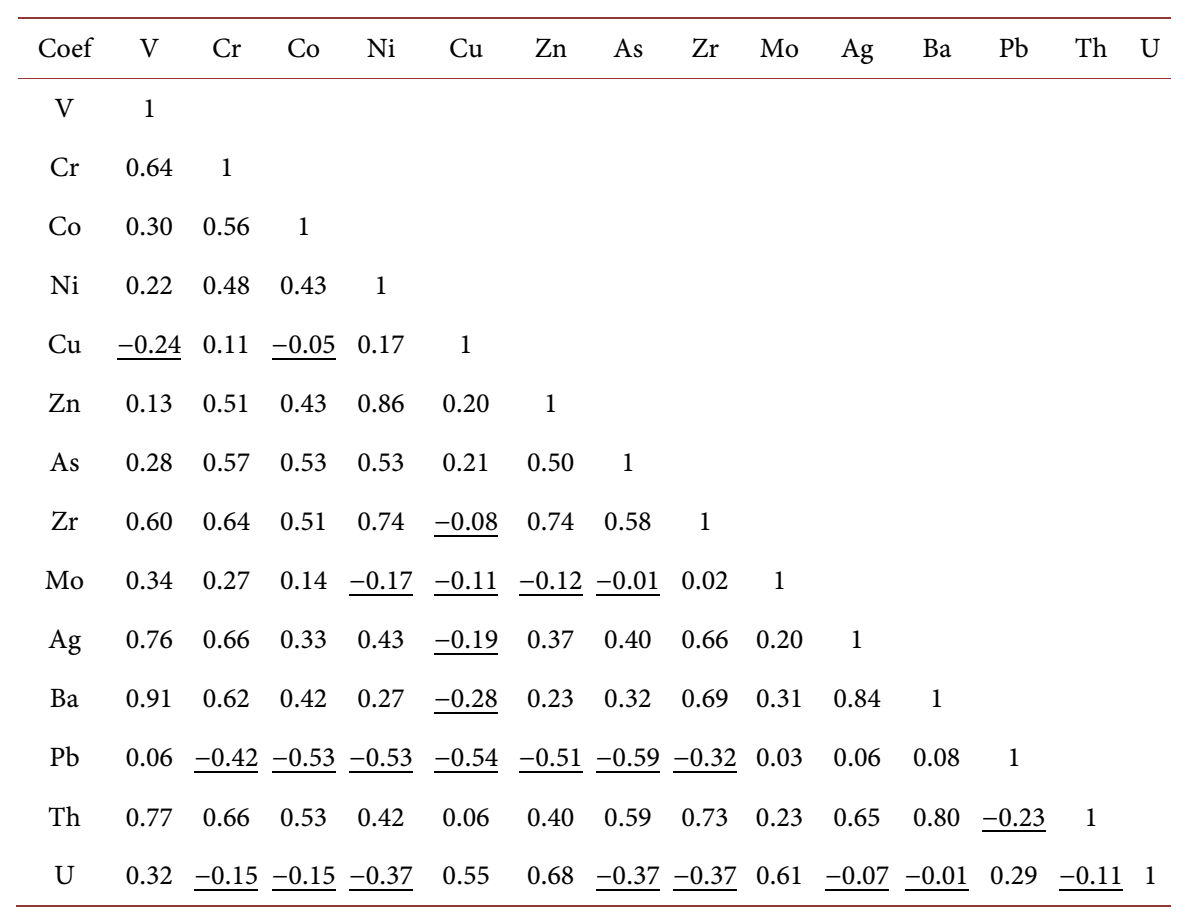

\section{Genesis Model for Tarat Sandstone Type Uranium}

The sandstone type uranium deposits of Tarat formation from Tim Mersoi basin, Niger which accumulated in the upper Paleozoic sedimentary part (Carboniferous) of the basin could have been derived from double felsic to mafic rocks of the Air Massif. These sandstones occur in medium to coarse-graineds and stones deposited in a continental fluvio-deltaic sedimentary environment 
Table 6. Results of correlation analysis between $\mathrm{U}>100 \mathrm{ppm}$ and REE.

\begin{tabular}{cccccccccccccccc}
\hline Coef. & $\mathrm{La}$ & $\mathrm{Ce}$ & $\mathrm{Pr}$ & $\mathrm{Nd}$ & $\mathrm{Sm}$ & $\mathrm{Eu}$ & $\mathrm{Gd}$ & $\mathrm{Tb}$ & $\mathrm{Dy}$ & $\mathrm{Ho}$ & $\mathrm{Er}$ & $\mathrm{Tm}$ & $\mathrm{Yb}$ & $\mathrm{Lu}$ & $\mathrm{U}$ \\
\hline $\mathrm{La}$ & 1 & & & & & & & & & & & & & \\
$\mathrm{Ce}$ & 0.91 & 1 & & & & & & & & & & & & \\
$\mathrm{Pr}$ & 0.75 & 0.88 & 1 & & & & & & & & & & & \\
$\mathrm{Nd}$ & 0.84 & 0.79 & 0.54 & 1 & & & & & & & & & & \\
$\mathrm{Sm}$ & 0.87 & 0.9 & 0.79 & 0.89 & 1 & & & & & & & & & \\
$\mathrm{Eu}$ & 0.83 & 0.89 & 0.76 & 0.87 & 0.94 & 1 & & & & & & & & \\
$\mathrm{Gd}$ & 0.79 & 0.85 & 0.74 & 0.87 & 0.94 & 0.95 & 1 & & & & & & & \\
$\mathrm{~Tb}$ & 0.45 & 0.54 & 0.51 & 0.43 & 0.46 & 0.53 & 0.57 & 1 & & & & & & \\
$\mathrm{Dy}$ & 0.76 & 0.8 & 0.64 & 0.79 & 0.87 & 0.85 & 0.86 & 0.49 & 1 & & & & & \\
$\mathrm{Ho}$ & 0.45 & 0.56 & 0.63 & 0.42 & 0.61 & 0.58 & 0.53 & 0.37 & 0.56 & 1 & & & & \\
$\mathrm{Er}$ & 0.78 & 0.73 & 0.59 & 0.82 & 0.85 & 0.81 & 0.8 & 0.29 & 0.78 & 0.4 & 1 & & & & \\
$\mathrm{Tm}$ & 0.73 & 0.69 & 0.53 & 0.69 & 0.77 & 0.71 & 0.68 & 0.1 & 0.71 & 0.31 & 0.89 & 1 & & & \\
$\mathrm{Yb}$ & 0.84 & 0.78 & 0.63 & 0.87 & 0.88 & 0.84 & 0.86 & 0.38 & 0.76 & 0.4 & 0.95 & 0.84 & 1 & & \\
$\mathrm{Lu}$ & 0.66 & 0.59 & 0.54 & 0.68 & 0.73 & 0.68 & 0.67 & 0.17 & 0.62 & 0.39 & 0.78 & 0.75 & 0.73 & 1 & \\
$\mathrm{U}$ & 0.38 & 0.28 & 0.01 & 0.25 & 0.12 & 0.09 & $\underline{-0.06}$ & $\underline{-0.04}$ & $\underline{-0.03}$ & $\underline{-0.2}$ & $\underline{-0.21}$ & $\underline{-0.26}$ & $\underline{-0.3}$ & $\underline{\underline{-0.08}}$ & 1 \\
\hline & & & & & & & & & & & & & & \\
\hline
\end{tabular}

affected by passive margin (PM) tectonic setting. Impermeable shale/mudstone units are interbedded in the sedimentary sequence and often occur immediately above and below the mineralized sandstone. Uranium is precipitated under reducing conditions caused by a variety of reducing agents within the sandstone which includes carbonaceous material (detrital plant debris, amorphous humate, marine algae), sulphides (pyrite, H2S), hydrocarbons (petroleum), and interbedded basic volcanics abundant ferromagnesian minerals (chlorite) (Figure 36):

$>$ Considerable proportion of uranium was leached during the weathering of the mafic and felsic rocks of Air Massif;

Significant $U$ mineralization is associated with the following stratigraphic unit of Carboniferous Upper Tagora;

Uranium occurs in the association U-Mo-Pb or U-Zn-Ni-Pb;

> Mineralization is controlled by the major fault In Azaoua lineament fault NS of Arlit in the West, the N70 Tin Adrar "faisceau" in the North, the N30 Mouron accident in the Southeast and N30 Autriche accident in the West;

Mineralization is limited to cement less porous, fluviatile sandstones with a high permeability, allowing easy circulation of mineralized fluids of from west to east usually capped and underlain by impermeable mudstone or clay-rich units;

Uranium is precipitated in areas of suitable reducing environment of arid to humid climatic conditions rich in organic matter.

\section{Conclusions}

The sandstone-type uranium deposits of Tarat formation from Tim Mersoi basin, Niger which accumulated in the upper Paleozoic sedimentary part 


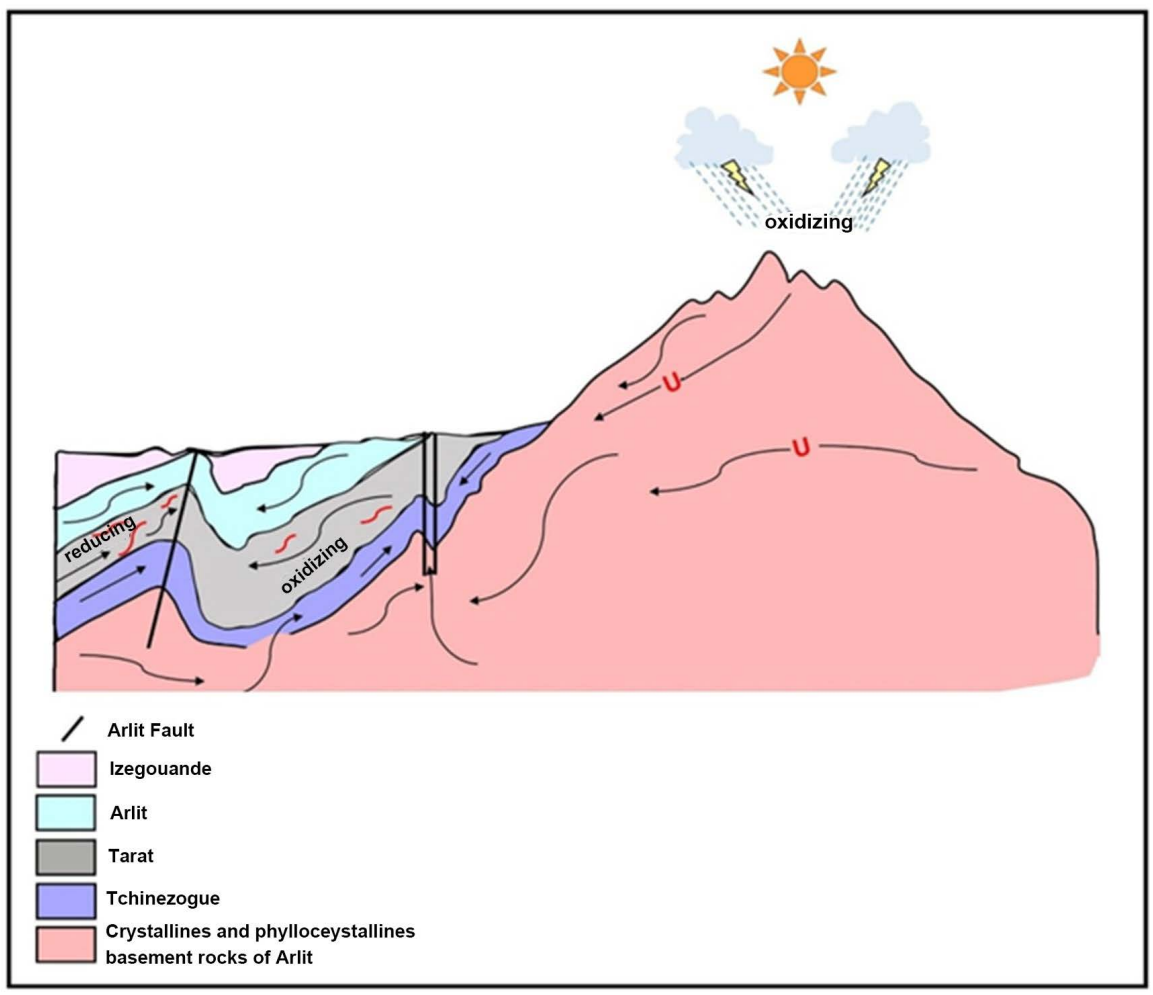

Figure 36. Genesis model for Tarat sandstone type uranium deposit.

(Carboniferous) of the basin are geochemically classified as Protoquarzite (i.e. lithearenite and sublitharenite), arkose, subarkose, wacke and quartz arenite varied in their maturity of granite-gneiss terrain and/or from pre-existing sedimentary terrain materials. The trace element ratios are consistent with most sandstone being derived from a double source mafic and felsic. Major, trace elements and REE ratios and diagrams suggest that sediments were derived from felsic source rocks. The source area may have contained quartzose sedimentary rocks. The chemical weathering indices (CIA, CIW and PIA) revealed intermediate to intense weathering conditions either in the source area or during transportation. The studied sandstones are inferred as highly mature sediments evidenced from their high $\mathrm{SiO}_{2} / \mathrm{Al}_{2} \mathrm{O}_{3}>1$ and the presence of the ultra-stable clay minerals, smectite, kaolinite, chlorite and illite. Chondrite-normalized REE patterns for studied samples display high LREE/HREE ratio, flat HREE pattern and pronounced negative $\mathrm{Eu}$ and $\mathrm{Ce}$ anomalies and in general correlate well with the NASC and PAAS average composition.

The sandstone-type uranium deposits of Tarat formation present $\mathrm{Th} / \mathrm{U}<3$ ratio suggesting high uranium enrichment over crust average composition. From factor analysis it is concluded that a considerable proportion of uranium was leached during the weathering of the mafic and felsic rocks of Air Massif and uranium occurred in the association $\mathrm{U}-\mathrm{Mo}-\mathrm{Pb}$ or $\mathrm{U}-\mathrm{Zn}-\mathrm{Ni}-\mathrm{Pb}$ structurally controlled by the major fault in Azaoua lineament fault NS of Arlit in the West, the N70 Tin Adrar "faisceau" in the North, the N30 ${ }^{\circ}$ Mouron accident in the 
Southeast and N30 Autriche accident in the West. The fluviatile sandstones with a high permeability, allowed easy circulation of mineralized fluids from west to east usually capped and underlain by impermeable mudstone or clay-rich units and uranium precipitated in areas of suitable reducing environment of arid to humid climatic conditions rich in organic matter affected by passive margin (PM) tectonic setting.

\section{Acknowledgements}

The authors are grateful to, and acknowledge the efforts of the staffs of the geological department of SOMAIR (Arlit) for their collaboration during our fieldwork and sampling. The corresponding author is also grateful to both the UNESCO-GREATWALL Fellowship and CV Raman International Fellowship for African Researcher for financial assistance to conduct this study. We indebted to the staffs of geochemical laboratories of IIT, Roorkee and Nanjing University for guidance during the analysis. Sincere thanks to the reviewers for their observations which have greatly improved the manuscript.

\section{Conflicts of Interest}

The authors have not declared any conflict of interests.

\section{References}

[1] Bonnamy, S. (1981) Relations matières organiques-Métaux (U-V-Ni), Etude en microscopie et diffraction électroniques. Thèse de 3ème cycle, Université Orléans, $81 \mathrm{p}$.

[2] Dill, H. (1986) Metallogenesis of Early Paleozoic Graptolite Shales from the Graefenthal Horst (Northern Bavaria Federal Republic of Germany). Economic Geology, 81, 883-893. https://doi.org/10.2113/gsecongeo.81.4.889

[3] Fedo, C.M., Nesbitt, H.W. and Young, G.M. (1995) Unraveling the Effects of Potassium Metasomatism in Sedimentary Rocks and Paleosols, with Implications for Paleoweathering Conditions and Provenance. Geology, 23, 921-924. https://doi.org/10.1130/0091-7613(1995)023<0921:UTEOPM>2.3.CO;2

[4] Hallberg, R.O. (1976) A Geochemical Method for Investigation of Palaeoredox Conditions in Sediments: Ambio. Special Report, 4, 138-147.

[5] Bowden, P., Van Breemen, O., Hutchison, J. and Turner, D.C. (1976) Palaeozoic and Mesozoic Age Trends for Some Ring Complexes in Niger and Nigéria. Nature, 259, 297299. https://doi.org/10.1038/259297a0

[6] Cavellec, S. (2006) Evolution diagénétique du Bassin de Tim Mersoï et conséquences pour lagenèse des minéralisations uranifères dansless formations du Guézouman et du Tarat (district Arlit-Akokan, Niger). Thèse de Doctorat de l'Université de Paris-Sud, $463 \mathrm{p}$.

[7] Elhamet, M.O. (1983) Analyse géologique et pétrographique de la formation de Tarat dansLes carrières Somaïr (Paléozoïque supérieur). Essai d'interprétation paléoclimatique à la lumière de l'épisode glaciairedévono-carbonifère (Région d'Arlit-Niger septentrional). Thèse Université de Dijon (France) et Université de Niamey (Niger), 279 p. 
[8] Forbes, P. (1989) Rôles des structures sédimentaires et techniques, du volcanismalcalin régional et des fluidesdiagénétiques-hydrothermaux pour la formation des minéralisations à U-Zr-Zn-V-Mo d'Akouta (Niger). Thèse de l'Université de Bourgogne, $375 \mathrm{p}$.

[9] Gerbeaud, O. (2006) Evolution structurale de bassin de Tim Mersoï: Déformation de la couverture sédimentaire, relation des gisements uranifères du secteur d'Arlit (Niger). Thèse de l'Université deParis XI Orsay, 270 p.

[10] Liégeois, J.P., Benhallou, A., Azzouni-Sekkal, A., Yahiaoui, R. and Bonin, B. (2005) The Hoggar Swell and Volcanism: Reactivation of the Precambrian Tuareg Shield during Alpine Convergence and West African Cenozoic Volcanism. In: Foulger, G.R., Natland, J.H. and Anderson, D.L., Eds., Plates, Plumes, and Paradigms, Geological Society of America Special Paper, 379-400.

https://doi.org/10.1130/0-8137-2388-4.379

[11] Harouna, M. (1991) Contribution à l'étude des substances carbonnées dans les bassins paléozoïques de la bordure occidentale du massif de l'Aïr (Républuque du Niger) Implications sédimentologiques et géochimiques. Thèse de l'Université d'Orléans, $284 \mathrm{p}$.

[12] Perez, J.P. (1985) Nouvelles données sur le complexe granitique anorogénique de Taghouaji (République du Niger). Influence des fluides au cours de la cristallisation. Thèse de l'Université de Nancy I, 296 p.

[13] Valance, J. (2007) Modèle métallogénique du gisement d’Immouraren (Niger). Rapport CREGU, 104 p.

[14] Valsardieu, C. (1971) Etude géologique et paléogéographique du bassin du Tim Mersoï, région d'Agadès (République du Niger). Thèse université de Nice, 155-518.

[15] Yahaya, M. (1992) Dynamique sédimentaire du Guezouman et des formations viseennessousjacentes en liaison avec la tectonique, le volcanisme et le climat: Paléomilieux des gîtes uranifères d'Arlit (Niger). Thèse Université de Bourgogne-Centre des Sciences de la Terre, $357 \mathrm{p}$.

[16] Wagani, I. (2007) Potentialités uranifères des sources volcaniques envisageables pour la formation des minéralisations de la région d'Arlit (Niger). Thèse de l’Université de Paris XI, Orsay, 283 p.

[17] Adel, I., Akarish, M. and El-Gohary, A.M. (2011) Provenance and Source Area Weathering Derived from the Geochemistry of Pre-Cenomanian Sandstones, East Sinai, Egypt. Journal of Applied Sciences, 11, 3070-3088. https://doi.org/10.3923/jas.2011.3070.3088

[18] Armstrong-Altrin, J.S., Lee, Y.I., Kasper-Zubillaga, J.J., Carranza-Edwards, A., Garcia, D., Eby, N., Balaram, V. and Cruz-Ortiz, N.L. (2012) Geochemistry of Beach Sands along Thewestern Gulf of Mexico, Mexico: Implication for Provenance. Chemie der Erde-Geochemistry, 72, 345-362.

[19] Armstrong-Altrin, J.S., Lee, Y.I., Verma, S.P. and Ramasamy, S. (2004) Geochemistry of Sandstones from the Upper Miocene Kudankulam Formation, Southern India: Implications for Provenance, Weathering, and Tectonic Setting. Journal of Sedimentary Research, 74, 285-297. https://doi.org/10.1306/082803740285

[20] Bhatia, M.R. and Crook, K.A.W. (1986) Trace Element Characteristics of Graywackes and Tectonic Setting Discrimination of Sedimentary Basins. Contributions to Mineralogy and Petrology, 92, 181-193. https://doi.org/10.1007/BF00375292

[21] Cullers, R.L. (1994) The Controls on the Major and Trace Element Variation of Shales, Siltstones, and Sandstones of Pennsylvanian-Permian Age from Uplifted 
Continental Blocks in Colorado to Platform Sediment in Kansas, USA. Geochimica et Cosmochimica Acta, 58, 4955-4972. https://doi.org/10.1016/0016-7037(94)90224-0

[22] McLennan, S.M. (1989) Rare Earth Elements in Sedimentary Rocks: Influence of Provenance and Sedimentary Processes. Geochemistry and Mineralogy of the Rare Earth Elements. Reviews in Mineralogy and Geochemistry, 21, 169-200.

[23] Moosavirad, S.M., Janardhana, M.R., Sethumadhav, M.S. and Narasimha, K.N.P. (2012) Geochemistry of Lower Jurassic Sandstones of Shemshak Formation, Kerman Basin, Central Iran: Provenance, Source Weathering and Tectonic Setting. Journal of the Geological Society of India, 79, 483-496. https://doi.org/10.1007/s12594-012-0073-4

[24] Nagarajan, R., Madhavaraju, J., Nagendra, R., Armstrong-Altrin, J.S. and Moutte, J. (2007) Geochemistry of Neoproterozoic Shales of Rabanpalli Formation, Bhima Basin, Northern Karnataka, Southern India: Implications for Provenance and Paleoredox Conditions. Revista Mexicana De Ciencias Geologicas, 24, 150-160.

[25] Nagarajan, R., Armstrong-Altrin, J.S., Nagendra, R., Madhavaraju, J. and Moutte, J. (2007) Petrography and Geochemistry of Terrigenous Sedimentary Rocks in the Neoproterozoic Rabanpalli Formation, Bhima Basin, Southern India: Implications for Paleoweathering Condition, Provenance, and Source Rock Composition. Journal of the Geological Society of India, 70, 297-312.

[26] Taylor, S.R. and McLennan, S.M. (1985) The Continental Crust: Its Composition and Evolution. Blackwell, Oxford, 312.

[27] Guiraud, R., Bosworth, W., Thierry, J. and Delplanque, A. (2005) Phanerozoic Geological Evolution of Northern and Central Africa: An Overview. Journal of African Earth Sciences, 43, 83-143. https://doi.org/10.1016/j.jafrearsci.2005.07.017

[28] Hambleton-Jones (2007) Uranium in Africa. Geological Society of South Africa Symposium: Uranium in Africa. Johannesburg.

[29] Scholtz. N (2009) Technical Report Batalene 1 and 2 Uranium Projects, Niger, 16-23.

[30] Kogbe, C.A. (1991) Stratigraphy and Tectonic History of the Iullemeden Basin in West Africa. South African Journal of Geology, 94, 19-31.

[31] Pacquet, A. (1968) Analcimes et argiles diagénétiques dans les formations sédimentaires de la région d'Agades (République du Niger). Mém. Serv. Carte Géol. Alsace-Lorraine, 27, $221 \mathrm{p}$.

[32] Joulia, F. (1959) Les séries primaires au N et NW de l'Aïr (Sahara Central). Discordances observées. Bulletin de la Société Géologique de France, 7, 192-196.

[33] Turpin, L., Clauer, N., Forbes, P. and Pagel, M. (1991) U-Pb, Sm-Nd and K-Ar Systematic of the Akouta Uranium Deposit, Niger. Chemical Geology, 87, 217-230.

[34] Konate, M., Denis, M., Yahaya, M. and Guiraud, M. (2007) Structuration extensive et transtansive au devono-dinantien du bassin de tim-mersoi (bordure occidentale de l'Air, NORD NIGER.). Annales de l'Université de Ouagadougou-Série C. 005, juin 2007.

[35] Helvoort, P.J., Filzmoser, P. and Gaans, P.F.M. (2005) Sequential Factor Analysis as a New Approach to Multivariate Analysis of Heterogeneous Geochemical Datasets: An Application to a Bulk Chemical Characterization of Fluvial Deposits (Rhine Meuse Delta, The Netherlands). Applied Geochemistry, 20, 2233-2251. https://doi.org/10.1016/j.apgeochem.2005.08.009

[36] Mouissi, S. and Alayat, H. (2016) Use of the Principal Component Analysis (PCA) 
for Physico Chemical Characterizations of an Aquatic Ecosystem Waters: Case of Oubeira Lake (Extreme Northeastern Algeria). Journal of Materials Environment, 7, 2216-2218.

[37] Omorinoye, O.A. and Adekeye, J.I.D. (2013) Soil Geochemistry Survey of Eruku and Environs. Journal of Environment and Earth Science, 3, 105-116.

http://www.iiste.org/

[38] Sun, X., Deng, J., Gong, Q., Wang, Q., Yang, L. and Zhao, Z. (2009) Kohonen Neural Network and Factor Analysis Based Approach to Geochemical Data Pattern Recognition. Journal of Geochemical Exploration, 103, 6-16. https://doi.org/10.1016/j.gexplo.2009.04.002

[39] Crook, K.A.W. (1974) Lithostratigraphy and Geotectonic: The Significance of Composition Variation in Flysch arenites (Graywackes). In: Dott, R.H. and Shaver, R.H., Eds., Modern and Ancient Geosynclinal Sedimentation, Society of Economic Paleontologists and Mineralogists, Tulsa, Okla, 304-310. https://doi.org/10.2110/pec.74.19.0304

[40] Feng, R. and Kerrich, R. (1990) Geochemistry of Fine-Grained Clastic Sediments in the Archean Abitibi Greenstones Belt, Canada: Implications for Provenance and Tectonic Setting. Geochimica et Cosmochimica Acta, 54, 1061-1081. https://doi.org/10.1016/0016-7037(90)90439-R

[41] Borges, J.B., Huh, Y., Moon, S. and Noh, H. (2008) Provenance and Weathering Control on River Bed Sediments of the Eastern Tibetan Plateau and the Russian Far East. Chemical Geology., 254, 52-72. https://doi.org/10.1016/j.chemgeo.2008.06.002

[42] Hayashi, K., Fujisawa, H., Holland, H. and Ohmoto, H. (1997) Geochemistry of 1.9 Ga Sedimentary Rocks from Northeastern Labrador, Canada. Geochimica et Cosmochimica Acta, 61, 4115-4137. https://doi.org/10.1016/S0016-7037(97)00214-7

[43] Herron, M.M. (1988) Geochemical Classification of Terrigenous Sands and Shales from Core or Log Data. Journal of Sedimentary Research, 58, 820-829.

[44] Jafarzadeh, M. and Hosseini-Barzi, M. (2008) Petrography and Geochemistry of Ahwaz Sandstone Member of Asmari Formation, Zagros, Iran: Implications on Provenance and Tectonic Setting. Revista Mexicana De Ciencias Geologicas, 25, 247-260.

[45] Lindsey, D.A. (1999) An Evaluation of Alternative Chemical Classifications of Sandstones. Open File Report 99-346, Electronic Edition. USGS.

[46] Asiedu, D.K., Hegner, E., Rocholl, A. and Atta-Peters, D. (2005) Provenance of Late Ordovician to Early Cretaceous Sedimentary Rocks from Southern Ghana, as Inferred from Nd Isotopes and Trace Elements. African Journal of Earth Science, 41, 316-328. https://doi.org/10.1016/j.jafrearsci.2005.05.003

[47] Cullers, R.L. (2002) Implications of Elemental Concentrations for Provenance, Redox Conditions, and Metamorphic Studies of Shales and Limestones near Pueblo, CO, USA. Chemical Geology, 191, 305-327. https://doi.org/10.1016/S0009-2541(02)00133-X

[48] Pettijohn, F.J. (1975) Sedimentary Rocks. $3^{\text {rd }}$ Edition, Harper and Row Publishers, New York, 628 p.

[49] Roser, B.P. and Korsch, R.J. (1988) Provenance Signatures of Sandstone-Mudstone Suites Determined Using Discriminant Function Analysis of Major-Element Data. Chemical Geology, 67, 119-139. https://doi.org/10.1016/0009-2541(88)90010-1

[50] Armstrong-Altrin, J.S. (2009) Provenance of Sands from Calzones, Acapulco, and Bahı Kino Beaches, Mexıco. Revista Mexicana De Ciencias Geologicas, 26, 764-782. 
[51] Roy, P.D., Caballeroa, M., Lozanoc, R. and Smykatz-Klossd, W. (2008) Geochemistry of Late Quaternary Sediments from Tecocomulco Lake, Central Mexico: Implication to Chemical Weathering and Provenance. Chemie der Erde-Geochemistry, 68, 383-393. https://doi.org/10.1016/j.chemer.2008.04.001

[52] Albright, E. (2004) Background Concentrations of Trace Elements in the Soil and Rocks of the Georgia Piedmont. MSc. Th., University of Georgia.

[53] Holland, H.D. (1986) The Chemistry of the Atmosphere and Ocean. In: Bhatia, M.R. and Crook, K.A.W., Eds., Trace Element Characteristics of Graywacke and Tectonic Setting Discrimination of Sedimentary Basins Contribution, Mineralogy Petrology, Vol. 92, 181-193.

[54] McLennan, S.M., Nance, W.B. and Taylor, S.R. (1980) Rare Earth Element-Thorium Correlations in Sedimentary Rocks and the Composition of the Continental Crust. Geochimica et Cosmochimica Acta, 44, 1833-1839. https://doi.org/10.1016/0016-7037(80)90232-X

[55] McLennan, S.M., Hemming, S., McDaniel, D.K. and Hanson, G.N. (1993) Geochemical Approaches to Sedimentation, Provenance and Tectonics. In: Johnson, M.J. and Basu, A., Eds., Processes Controlling the Composition of Clastic Sediments, Geological Society of Amercain Special Paper, USA, 21-40. https://doi.org/10.1130/SPE284-p21

[56] Shao, J., Yang, S. and Li, C. (2012) Chemical Indices (CIA and WIP) as Proxies for Integrated Chemical Weathering in China: Inferences from Analysis of Fluvial Sediments. Sedimentary Geology, 265-266, 110-120. https://doi.org/10.1016/j.sedgeo.2012.03.020

[57] Cullers, R.L. (2000) The Geochemistry of Shales, Siltstones and Sandstones of Pennsylvanian-Permian Age, Colorado, USA: Implications for Provenance and Metamorphic Studies. Lithos, 51, 181-203. https://doi.org/10.1016/S0024-4937(99)00063-8

[58] Dypvik, H. (1984) Geochemical Compositions and Depositional Conditions of Upper Jurassic and Lower Cretaceous Yorkshire Clays, England. Geological Magazine, 121, 488-514. https://doi.org/10.1017/S0016756800030028

[59] Fatima, S. and Khan, M.S. (2012) Petrographic and Geochemical Characteristics of Mesoproterozoic Kumbalgarh Clastic Rocks, NW Indian Shield: Implications for Provenance, Tectonic Setting, and Crustal Evolution. International Geology Review, 54, 1113-1144. https://doi.org/10.1080/00206814.2011.623032

[60] Haskin, L.A., Wildermane, T.R. and Haskin, M.A. (1968) An Accurate Procedure for the Determination of Rare Earthsbv Neutron Activation. Journal of Radioanalytical Chemistry, 1, 337-348.

[61] Cingolani, C.A., Manassero, M. and Abre, P. (2003) Compositional, Provenance, and Tectonic Setting of Ordovician Siliciclastic Rocks in the San Rafael Block: Southern Extension of the Precordillera Crustal Fragment, Argentina. Journal of South American Earth Sciences, 16, 91-106. https://doi.org/10.1016/S0895-9811(03)00021-X

[62] Bakkiaraj, D., Nagendra, R., Nagarajan, R. and Armstrong-Altrin, J.S. (2010) Geochemistry of Sandstones from the Upper Cretaceous Sillakkudi Formation, Cauvery Basin, Southern India: Implication for Provenance. Journal of the Geological Society of India, 76, 453-467. https://doi.org/10.1007/s12594-010-0128-3

[63] Harnois, L. (1988) The CIW Index: A New Chemical Index of Weathering. Sedimentary Geology, 55, 319-322. https://doi.org/10.1016/0037-0738(88)90137-6 
[64] Nesbitt, H.W. and Young, G.M. (1982) Early Proterozoic Climates and Plate Motions Inferred from Major Element Chemistry of Lutites. Nature, 299, 715-717. https://doi.org/10.1038/299715a0

[65] Jacobson, A.D., Blum, J.D., Chamberlain, C.P., Crew, D. and Koons, P.O. (2003) Climate and Tectonic Controls on Chemical Weathering in the New Zealand, Southern Alps. Geochemica Cosmochimica Acta, 67, 29-46. https://doi.org/10.1016/S0016-7037(02)01053-0

[66] Osae, S., Asiedu, D.K., Banoeng-Yakubo, B., Koeberl, C. and Dampare, S.B. (2006) Provenance and Tectonic Setting of Late Proterozoic Buem Sandstones of Southeastern Ghana: Evidence from Geochemistry and Detrital Modes. Journal of African Earth Sciences, 44, 85-96. https://doi.org/10.1016/j.jafrearsci.2005.11.009

[67] Selvaraj, K. and Chen, C.-T.A. (2006) Moderate Chemical Weathering of Subtropical Taiwan: Constraints from Solid Phase Geochemistry of Sediments and Sedimentary Rocks. Journal of Geology, 114, 101-116. https://doi.org/10.1086/498102

[68] Hossain, H.M.Z., Roser, B.P. and Kimura, J.I. (2010) Petrography and Whole-Rock Geochemistry of the Tertiary Sylhet Succession, Northeastern Bengal Basin, Bangladesh: Provenance and Source Area Weathering. Sedimentary Geology, 228, 171-183. https://doi.org/10.1016/j.sedgeo.2010.04.009

[69] Pettijohn, F.J., Potter, P.E. and Siever, R. (1987) Sand and Sandstone. Springer-Verlag, Berlin. https://doi.org/10.1007/978-1-4612-1066-5

[70] Raza, M., Ahmad, A.H.M., Khan, M.S. and Khan, F. (2012) Geochemistry and Detrital Modes of Proterozoic Sedimentary Rocks, Bayana Basin, North Delhi Fold Belt: Implications for Provenance and Source-Area Weathering. International Geology Review, 54, 111-129. https://doi.org/10.1080/00206814.2010.517044

[71] Wronkiewicz, D.J. and Condie, K.C. (1990) Geochemistry and Mineralogy of Sediments from the Ventersdorp and Transvaal Supergroups, South Africa: Cratonic Evolution during the Early Proterozoic. Geochimica et Cosmochimica Acta, 54, 343-354. https://doi.org/10.1016/0016-7037(90)90323-D

[72] Suttner, L.J. and Dutta, P.K. (1986) Alluvial Sandstones Composition and Paleoclimate, I, Framework Mineralogy. Journal of Sedimentary Petrology, 56, 329-345.

[73] Gupta, S., Banerjee, R., Babu, P.V.R., Parihar, P.S. and Maithani, P.B. (2012) Geochemistry of Uraniferous Banganapalle Sediments in the Western Part of Palnad Sub-Basin, Andhra Pradesh: Implications on Provenance and Paleo-Weathering. Gondwana Geological Magasine. Special, 13, 1-14.

[74] Jones, B. and Manning, D.C. (1994) Comparison of Geochemical Indices Used for the Interpretation of Paleo-Redox Conditions in Ancient Mudstones. Chemical Geology, 111, 110-131. https://doi.org/10.1016/0009-2541(94)90085-X

[75] Olungbenga, A.O. and Olubunmi, I. (2012) The Geochemistry of Claystone-Shale Deposits from the Maastritchian Patti Formation, Southern Bida Basin, Nigeria. Earth Sciences Research Journal, 16, 3-8.

[76] Nath, B.N., Bau, M., Ramalingeswara Rao, B. and Rao, Ch.M. (1997) Trace and Rare Earth Elemental Variation in Arabian Sea Sediments through a Transect across the Oxygen Minimum Zone. Geochimica et Cosmochimica Acta, 61, 2375-2388. https://doi.org/10.1016/S0016-7037(97)00094-X

[77] Armstrong-Altrin, J.S. and Verma, S.P. (2005) Critical Evaluation of Six Tectonic Setting Discrimination Diagrams Using Geochemical Data of Neogene Sediments from Known Tectonic Settings. Sedimentary Geology, 177, 115-129. https://doi.org/10.1016/j.sedgeo.2005.02.004 
[78] Bailey, J.C. (1981) Geochemical Criteria for a Refined Tectonic Discrimination of Orogenic Andesites. Chemical Geology, 38, 27-34. https://doi.org/10.1016/0009-2541(81)90135-2

[79] Murphy (2000) In Book of Geochemistry of Sedimentary Rocks: Provenance, Paleoweathering and Tectonic Setting. 71-75.

[80] Chabiron, A., Alyoshin, A.P., Cuney, M., Deloule, E., Golubev, V.N., Velitchkin, V.I. and Poty, B. (2001) Geochemistry of the Rhyolitic Magmas from the Streltsovka caldera (Transbaikalia, Russia): A Melt Inclusion Study. Chemical Geology, 175, 273-290. https://doi.org/10.1016/S0009-2541(00)00300-4

[81] Chemillac, R. (2004) Caractéristiques géochimiques originelles et transferts de matière lors de l'altération des roches volcaniques acides associées aux minéralisations uranifères. Thèse de Doctorat de l'Université de Nancy I, 385 p. 